\title{
MAGNETIC STRUCTURAL-PHASE ANALYSIS AS APPLIED TO DIAGNOSING AND EVALUATING THE LIFETIME OF PRODUCTS AND STRUCTURAL COMPONENTS PART 1
}

\author{
E. S. Gorkunov ${ }^{1 *}$ \\ ${ }^{1}$ Institute of Engineering Science, Ural Branch of the Russian Academy of Sciences, 34 Komsomolskaya st., \\ Ekaterinburg, Russian Federation
}

\begin{abstract}
*Corresponding author. E-mail: ges@imach.uran.ru ; address for correspondence: ul. Komsomolskaya 34, 620049, Ekaterinburg, Russian Federation. Tel.: +7 (343) 374-47-25; fax: +7 (343) 374-53-30
\end{abstract}

This paper initiates a survey of original papers on various divisions of magnetic structuralphase analysis. A schematic "tree of magnetic structural-phase analysis" has been drawn up, which offers an insight into the state of the art and prospects in the application of magnetic techniques to evaluating the structural state, phase composition and physical-mechanical properties of rolled stock, heat-treated steel and cast-iron products, to the nondestructive testing of the depth and hardness of layers in face-hardened products; it also gives an idea of laboratory and in-situ procedures of performing a magnetic phase analysis. Considering that the survey is extensive, it is divided into several parts.

Keywords: structure, phase composition, magnetic properties, hardness, heat treatment, magnetic characteristics, testing devices, attached electromagnets.

DOI: $10.17804 / 2410-9908.2015 .1 .006-040$

\section{References}

1. Kryloff M. Balance electro-magnetique pour lessal des proprietes des asiers et des fers. Revur Metallurgie, 1905, no. 2, pp. 425-440.

2. Mikheev M.N., Gorkunov E.S. Magnitnye metody strukturnogo analiza i nerazrushayushchego kontrolya [Magnetic methods of structural analysis and nondestructive testing]. Moscow, Nauka Publ., 1993, 251 p. (In Russian).

3. Scherbinin V.E., Gorkunov E.S. Magnitny control kachestva metallov [Magnetic testing of the quality of metals]. Ekaterinburg, UrO RAN Publ., 1996, 264 p. (In Russian).

4. Gorkunov E.S., Ulyanov A.I. Magnitnye metody i pribory kontrolya kachestva izdelii poroshkovoy metallurgii [Magnetic methods and devices for testing the quality of powdered metal products]. Ekaterinburg, UrO RAN Publ., 1996, 204 p. (In Russian).

5. Yensen T.D., Ziegler N.A. Magnetic properties of iron as affected by carbon, oxygen and grain-size. Trans. Amer. Soc. Met, 1935, vol. 23, pp. 556-557.

6. Sizoo G.J. Über den Zusammenhang zwischen Korngröße und magnetischen Eigenschaften bei reinem Eisen. Ztschr. Phys, 1928, Bd. 1, ss. 557-561.

7. Gutnov R.D., Sukhotin B.N., Sokol I.Ya. Proizvodstvo nizkouglerodistogo zheleza [Production of low-carbon iron]. Moscow, Metallurgiya Publ., 1973, pp. 7-20. (In Russian).

8. Litvinenko D.A., Matrosov J.I. Steel properties affected by controlled rolling. Stal, 1974, no. 10, pp. 931-936. (In Russian).

9. Drege V. Stal kak konstruktsyonny material [Steel as a structural material]. Moscow, Metallurgiya Publ., 1967, 375 p. (In Russian).

10. Kogan L.I., Kleiner I.M., Entin R.I. Peculiarities of austenite transformation in alloyed lowcarbon steels. FMM, 1976, vol. 41, iss. 1, pp. 118-123. (In Russian).

11. Oding I.A. Prochnost metallov [Strength of metals]. Moscow -Leningrad, ONTI MetP Publ., 1957, 565 p. (In Russian). 
12. Bernstein M.I. Struktura deformirovannykh splavov [The structure of deformed alloys]. Moscow, Metallurgiya Publ., 1977, 430 p. (In Russian).

13. Vister G.I., Dal V., Hengstenberg H. Effect of the conditions of rolling (in particular, the temperature at the end of rolling) on the mechanical properties of low-alloyed and low-carbon steels. Chiornye metally, 1962, no. 17, pp. 34-46. (In Russian).

14. Kneller E. Ferromagnetismus. Berlin, Göttingen, Heidelberg: Springer-Verlag Pabl., 1962, $792 \mathrm{p}$.

15. Lifshitz B.G. Fizicheskie svoistva metallov i splavov [The physical properties of metals and alloys]. Moscow, Mashgiz Publ., 1959, 368 p. (In Russian).

16. Mel'gui M.A., Vostrikov A.A., Zborovskii A.A. Magnetic inspection of the mechanical properties of cold-rolled steel sheet. The Soviet journal of nondestructive testing, 1971, vol. 7, no. 3, pp. 248-252.

17. Bida G.V., Gorkunov E.S., Shevnin V.M. Magnitny control mekhanicheskikh svoistv proka$t a$ [Magnetic testing of the mechanical properties of rolled products]. Ekaterinburg, UrO RAN Publ., 2002, 251 p. (In Russian).

18. Mikheev M.N., Gorkunov E.S. Magnetic method of nondestructive testing of the structure condition and strength characteristics of heat-treated parts (review). The Soviet Journal of Nondestructive Testing, 1985, vol. 21, no. 5, pp. 330-333.

19. Gorkunov E.S. Magnetic structure and phase analysis of ferromagnetic steels and alloys. Russian Journal of Nondestructive Testing, 1991, no. 4, pp. 231-259.

20. Morozova V.M., Mikheev M.N. Magnetic and electric properties of quenched and tempered carbon steels. Tr. IFM AN SSSR, 1965, iss. 24, pp. 26-35. (In Russian).

21. Mikheev M.N., Zhukova P.N., Tomilov G.S. Magnetic electric properties of differently heat-treated alloyed steels. Tr. IFM AN SSSR,1954, iss. 15, pp. 90-102. (In Russian).

22. Mikheev M.N., Somova V.M., Gorkunov E.S. Magnetic inspection for quality control of heat treatment of products made of structural steel grades 45 and 50 . The Soviet Journal of Nondestructive Testing, 1980, no. 7, pp. 495-500.

23. Mikheev M.N., Gorkunov E.S. Magnetic methods of testing the quenching and subsequent tempering of products made of low-allowed and structural steels. Tr. IFM AN SSSR, 1979, iss. 37, pp. 3-14. (In Russian).

24. Mikheev M.N., Gorkunov E.S., Somova V.M., Kut'kin A.B. Interrelation of the magnetic and mechanical properties with the structural state of hardened and tempered products. The Soviet Journal of Nondestructive Testing, 1982, vol. 18, no. 9, pp. 725-732.

25. Zhukova P.N., Mikheev M.N. Magnetic properties of differently heat-treated chromiumnickel-molybdenum steels. ZhTF, 1948, vol.18, iss.2, pp. 187-196. (In Russian).

26. Kuznetsov I.A., Bagrov A.I., Radionova L.Kh., Somova V.M. Magnetic, electrical and mechanical properties of steel 35SGM after hardening and tempering. The Soviet Journal of Nondestructive Testing, 1978, vol. 14, no. 7, pp. 609-614.

27. Gorkunov E.S., Mikheev M.N., Dunaev F.N. Effects of heat treatment on the magnetic and electrical properties of $18 \mathrm{KhNVA}, 34 \mathrm{KhN} 3 \mathrm{M}$, and U9A steels. The Soviet Journal of Nondestructive Testing, 1975, no. 3, pp. 368-373.

28. Mikheev M.N., Gorkunov E.S. Magnetic methods of monitoring Quality of heat treatment. Melbourne: Ninth world conference on non-destructive testing. 1979. 4A-10.

29. Mikheev M.N., Somova V.M., Gorkunov E. S. Nondestructive magnetic quality-control method for the heat treatment of steels $30 \mathrm{KhN} 2 \mathrm{MFA}$ and $40 \mathrm{Kh}$. The Soviet Journal of Nondestructive Testing, 1979, no. 10, pp. 863-868.

30. Mikheev M.N., Gorkunov E.S. On possible causes of a difference in the magnetization reversal processes occurring in weak and medium magnetic fields of heat-treated structural steels. $F M M, 1981$, vol. 51, iss. 4, pp. 749-755. (In Russian). 
31. Gorkunov E.S., Kostin V.N., Tartachnaya M.V., Glazistov A.G., SHalaev V.N. Magnetic inspection of products of steels $7 \mathrm{Kh} 3,9 \mathrm{KhF}, 50 \mathrm{KhNM}, \mathrm{U} 10 \mathrm{~A}$ after low and medium tempering. The Soviet Journal of Nondestructive Testing, 1990, no.1, pp. 65-70.

32. Gorkunov E.S., Gavrilova L.D., Nichipuruk A.P. Magnetic and electromagnetic method for quality control of quenching and tempering and determination of retained austenite in $95 \mathrm{Kh} 18$ steel products. Russian Journal of Nondestructive Testing, 1995, no. 12, pp. 897-905.

33. Mikheev M.N., Gorkunov E.S., Dunaev F.N. Nondestructive magnetic inspection of hardened and tempered parts of low-alloy constructional and plain carbon steel. I. The Soviet Journal of Nondestructive Testing, 1977, no. 6, pp. 613-617.

34. Mikheev M.N., Gorkunov E.S., Dunaev F.N. Nondestructive magnetic inspection of hardened and tempered parts of low-alloy constructional and plain carbon steel. II. The Soviet Journal of Nondestructive Testing, 1977, no. 6, pp. 618-622.

35. Mikheev M.N., Tomilov G.S., Pomukhin M.F Magnetic testing of the quality of quenching and tempering of the parts of ball and roller bearings. Zavod. Lab, 1956, no. 5, pp. 549-555. (In Russian).

36. Mikheev M.N., Gorkunov E.S., Antonova A.V., Shirobokov M.I., Nikitin V.V. Differential measuring instrument of magnetic characteristics. The Soviet Journal of Nondestructive Testing, 1982, no.12, pp. $982-984$.

37. Filippov A.V., Gorkunov E.S., Kuzminykh V.P. The Dimkh-2 magnetic characteristic differential gauge. The Soviet Journal of Nondestructive Testing, 1990, no. 4, pp. 280-283.

38. Gorkunov E.S., Surin G.V., Nichipuruk A.P. Using differential magnetic structuroscopes to test the quality of composite materials. Mekhanika Kompozitnykh Materialov, 1992, no.6, pp. 838-840. (In Russian).

39. Gorkunov E.S., Somova V.M., Buldakova N.B. Resistance of the remanent magnetization state of steel subjected to various heat treatments to the effect of constant demagnetizing fields. The Soviet Journal of Nondestructive Testing, 1986, vol. 22, iss. 9, pp. 586-594.

40. Gorkunov E.S., Batukhtina I.N. Examination of the kinetics of magnetic properties in tempering structural steels with special reference to active inspection of their quality. The Soviet Journal of Nondestructive Testing, 1987, vol. 23, iss. 3, pp. 177-182.

41. Perkas M.D., Kardonskii V.M. Vysokoprochnye martensitostareyuschie stali [Maraging High-Strength Steels]. Moscow, Metallurgiya Publ., 1970, 224 p. (In Russian).

42. Perkas M.D. The structure and properties of high-strength steels with aging martensite. Metallovedenie i termicheskaya obrabotka metallov, 1970, no. 7, pp. 12-24. (In Russian).

43. Lifshits B.G., Kraposhin V.S. Linetskii Ya.L. Fizicheskie svoistva metallov i splavov [Physical Properties of Metals and Alloys]. Moscow, Metallurgiya Publ., 1980, 318 p. (In Russian).

44. Dekhtyar I.Ya., Polotnyak V.V., Gorbach B.G., etc Magnetic properties of aluminium- and titanium-alloyed iron-nickel alloys tempered at temperatures ranging within $\alpha \rightarrow \gamma$ transformation. Metallofizika, 1984, vol. 6, no. 2, pp. 65-69. (In Russian).

45. Sokol I.Ya. Dvukhfaznye stali [Two-Phase Steels]. Moscow, Metallurgiya Publ., 1974, 216 p. (In Russian).

46. Gudremon E. Spetsialnye stali [Special Steels]. Moscow, Metallurgiya Publ., 1966, vol. 1, 736 p. (In Russian).

47. Zabilskii V.V., Gorkunov E.S., Ugarova N.I., Murakhovskii I.M. Examination of the possibilities of magnetic inspection of the susceptibility of a two-phase ferritic-austenitic steel to embrittlement. The Soviet Journal of Nondestructive Testing, 1987, vol. 23, no. 3, pp. 177-182.

48. Hoshino A., Nakao K., Kanao M. Influence of austenite on toughness of two phase stainless steels. Trans. Nat.Res. Inst. Met., 1980, vol. 22, no. 4, pp. 185-194.

49. Maehara C., Koike M., Fujine N., Kunitake T. Precipitation behavior of $\sigma$-phase induplex phase stainless. Tetsu to hanage, 1981, vol. 67 , no. 3, pp. 577-587. 
50. Korshunov L.G., Makarov A.V., Osintseva A.L. Studying the wear resistance and structural transformations in the abrasive wear of laser-hardened steel U8. Trenie i iznos, 1988, vol. 9, no. 1, pp. 52-59. (In Russian).

51. Makarov A.V., Korshunov L.G., Osintseva A.L. The effect of tempering and frictional heating on the wear resistance of laser-hardened steel U8. Trenie $i$ iznos, 1991, vol. 12, no. 5, pp. 870-878. (In Russian).

52. Korshunov L.G., Makarov A.V., Chernenko N.L. The structural aspects of the wear resistance of martensitic steels. FMM, 1994, vol. 78, iss. 4, pp. 128-146. (In Russian).

53. Gorkunov E.S., Somova V.M., Makarov A.V., Kogan L.Kh., Korshunov L.G. Magnetic and electromagnetic methods of evaluating the wear resistance of steel products. Russian Journal of Nondestructive Testing, 1995, no. 6, pp. 427-432.

54. Morozova V.M., Mikheev M.N., Pomortseva L.V. Magnetic and electrical properties of the 17KhN2, 20Kh3A, 17Kh3MA steels and the cemented layers on them. Defektoskopiya, 1966, no. 5, pp. 7-17. (In Russian).

55. Mikheev M.N. A magnetic method for testing the thickness of quenched, cemented, nitrogenized and decarburized layers on steel products. Izv. AN SSSR (OTN), 1943, no. 5-6, pp. 53-68. (In Russian).

56. Kuznetsov I.A., Somova V.M., Skripova N.M. Magnetic, electrical and mechanical properties of $12 \mathrm{KhN} 3 \mathrm{~A}$ steel and it's case-hardened layers. The Soviet journal of nondestructive testing, 1974, vol. 10, no. 4, pp. 464-468.

57. Kuznetsov I.A., Somova V.M., Tzarkova T.P., Baschkirov Yu.P. Magnetic, electromagnetic, mechanical properties of steels 20KhGR, 20KhGNR and their cemented layers. In Book: Struktura $i$ svoistva tverdykh tel. Sverdlovsk, UrGU Publ., 1973, vol. 1, pp. 164-184. (In Russian).

58. Kuznetsov I.A., Skripova N.M. Magnetic, electrical and mechanical properties of 12KhN3A and $12 \mathrm{Kh} 2 \mathrm{~N} 4 \mathrm{~A}$ steels and of case-hardened layers on them. The Soviet journal of nondestructive testing, 1982, vol. 18, no. 12, pp. 985-990.

59. Kuznetsov I.A., Tsarkova T.P., Shepelev E.V. Electromagnetomechanical properties of cold-worked and heat-treated $11 \mathrm{YuA}$ steel. The Soviet journal of nondestructive testing, 1978, vol. 14, no. 1, pp. 17-23.

60. Mikheev M.N., Fridman L.A., Morozova V.M., Tabachnik V.P., Biba G.V., Gorkunov E.S., Chernova G.S. Using coercimeters with attached electromagnets to inspect massive steel objects. The Soviet journal of nondestructive testing, 1978, vol. 14, no. 8, pp. 713-717.

61. Mikheev M.N., Kuznetsov I.A., Tomilov G.S., Fillipov S.D. Magnetic testing of the depth of a hardened layer and the hardness of steel parts hardened by high-frequency currents. Trudy IFM AN SSSR. Sverdlovsk, 1959, vol. 21, pp. 205-208. (In Russian).

62. Mikheev M.N., Morozova V.M., Tomilov G.S., etc. Magnetic testing of the depth of the active hardened layer of rolls in cold rolling. Zavodskaya laboratoriya. 1956, no. 1, pp. 52-56. (In Russian).

63. Mikheev M.N., Morozova V.M., Surin G.V., etc. Effects of coercive force and thickness of tested articles on the outputs of coercive force meters having an attached electromagnet. The Soviet journal of nondestructive testing, 1970, no. 5, pp. 575-577.

64. Gorkunov E.S., Ermolaev V.G., Lapidus B.M., Lyashenko N.A., Sterkhov V.G., Ulyanov A.I. Magnetic methods of checking the depth of the hardened layer of machine saw blades. The Soviet Journal of Nondestructive Testing, 1981, vol. 17, no. 11, pp. 878-881.

65. Mikheev M.N., Gorkunov E.S., Vostrotina T.I. Inspecting the heat-treatment quality of higtfrequency induction-hardened parts. The Soviet Journal of Nondestructive Testing, 1976, no. 1 , pp. 49-52.

66. Aldicheva E.S., Valiev M.M., Kaganov Z.G., Kusimov S.T. Quality control of the case hardening of steel products made from steel 45.The Soviet journal of nondestructive testing, 1976, vol. 12 , no. 6 , pp. 612-614. 
67. Gorkunov E.S., Lapidus B.M. Magnetic properties of double-layer ferromagnets as applied to testing the quality of surface-hardened products. In Book: Sb. Strukturno-fazovye prevrascheniya $v$ metallakh: problemy prochnosti $i$ plastichnosti. Sverdlovsk, UNTs AN SSSR Publ., 1987, pp. 103-110. (In Russian).

68. Gorkunov E.S., Lapidus B.M. Elektromagnitnye metody i sredstva kontrolya kachestva poverkhnostnogo uprochneniya stalnykh izdely [Electromagnetic methods and devices for testing the quality of surface hardening of steel products]. Sverdlovsk, RISO UNTs AN SSSR Publ., 1986, 47 p. (In Russian).

69. Gorkunov E.S., Lapidus B.M. Magnitnye metody kontrolya kachestva poverkhnostnogo uprochneniya stalnykh izdely [Magnetic methods for testing the quality of surface hardening of steel products]. Sverdlovsk, RISO UNTs AN SSSR Publ., 1986, 56 p. (In Russian).

70. Lapidus B.M., Gorkunov E.S., Voronov S.F. A magnetic method of determining the structural state and thickness of hardened layers on steel components. Russian Journal of Nondestructive Testing, 1992, vol. 74, no. 6, pp. 593-597.

71. Gorkunov E.S., Zakharov V.A. Coercimeters with magnetic attachments (Review). Russian Journal of Nondestructive Testing, 1995, no. 8, pp. 625-641. 
DOI: $10.17804 / 2410-9908.2015 .1 .006-040$

\title{
ИСПОЛЬЗОВАНИЕ МАГНИТНОГО СТРУКТУРНО-ФАЗОВОГО АНАЛИЗА ДЛЯ ДИАГНОСТИКИ И ОЦЕНКИ РЕСУРСА ИЗДЕЛИЙ И ЭЛЕМЕНТОВ КОНСТРУКЦИЙ ЧАСТЬ 1
}

\author{
Э. С. Горкунов ${ }^{1 *}$ \\ ${ }^{1}$ Федеральное государственное бюджетное учреждение науки Институт машиноведения Уральского отделе- \\ ния Российской академии наук, ул. Комсомольская, 34, Екатеринбург, Российская Федерация \\ *Ответственный автор. Электронная почта: ges@imach.uran.ru; адрес для переписки: ул. Комсомольская, 34, \\ Екатеринбург, Российская Федерация. Телефон: +7 (343) 374-47-25; \\ факс: +7 (343) 374-53-30
}

Настоящая статья открывает обзор оригинальных работ по различным разделам магнитного структурно-фазового анализа. Автором сформировано схематическое «дерево магнитного структурно-фазового анализа», которое позволяет получить представление о состоянии и перспективах использования магнитных методов для оценки структурного состояния, фазового состава, физико-механических свойств проката, термически обработанных стальных изделий; применения данных методов для неразрушающего контроля глубины и твердости слоёв поверхностно упрочненных изделий, а также о методах проведения магнитного фазового анализа в лабораторных и промышленных условиях. Ввиду большого объема работа разделена на несколько частей.

Ключевые слова: структура, фазовый состав, магнитные свойства, твердость, термическая обработка, магнитные характеристики, приборы контроля, приставные электромагниты.

\section{1. Введение}

История создания и развития магнитных методов контроля структурного состояния и фазового состава очень тесно связана с Уралом и его заводами. Первыми заводами России, широко применившими магнитные методы в 1894 г. для контроля качества структуры и прочностных характеристик заготовок снарядов, оружейных и артиллерийских стволов были Тульский и Ижевский императорские военные заводы и Златоустовский горнометаллургический завод на Урале [1]. Уже в то время было показано, что существующие методы оценки качества металла по твёрдости весьма грубы и не отвечают требованиям промышленности по производительности. Созданные первые магнитные установки, названные электромагнитными балансами, успешно использовались для оценки качества закалки, прокаливаемости и наклёпа в стальных изделиях (рис. 1). Первые попытки введения данного вида контроля ружейной продукции позволили выявить на Ижевском заводе до $65 \%$ бракованных стволов военных ружей.

В сентябре 1902 г. на съезде химиков и металлургов Урала обсуждался вопрос об опыте использования «электромагнитных балансов» и была продемонстрирована новая возможность магнитных методов - оценка содержания углерода в стали. При обсуждении пришли к выводу, что "магнитный анализ стали приобретает для металлургов такое же значение, какое имеет для химиков химический анализ; металлофизические исследования стали дают качественные показатели, реже - количественные, к тому же проверка металла данным способом требует значительного индивидуального мастерства и опыта. Результаты же магнитного анализа выражаются в точных цифрах и позволяют качественно выполнять измерения, не оставляя места для 
субъективизма". После недолгого использования этих методов для оценки качества закалки изделий, прокаливаемости и наклёпа в сталях эти методы были незаслуженно забыты.

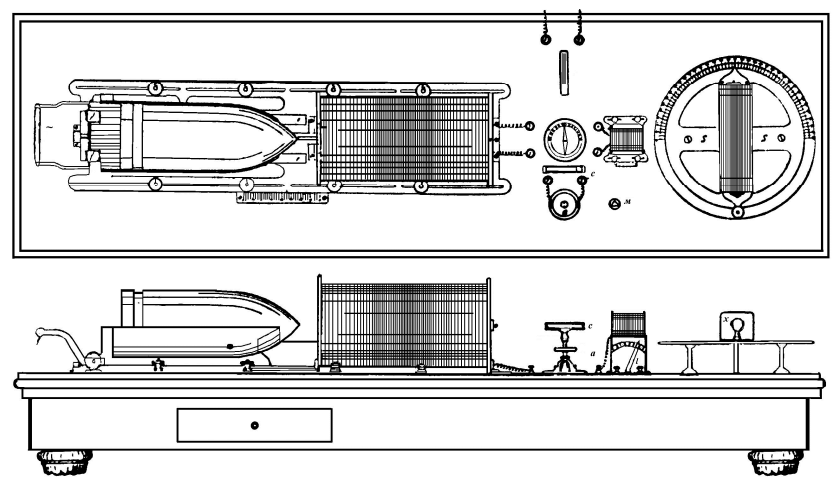

Рис. 1. Электромагнитный баланс [1]

Новый виток развития магнитных методов неразрушающего контроля на Урале начинается с 1932 г., когда по инициативе академика Абрама Фёдоровича Иоффе создаётся Уральский физико-технический институт. Ведущие ученые этого института Р.И. Янус, М.Н. Михеев и П.А. Халилеев на стыке научных направлений - физики магнитных явлений и физического металловедения - формируют новое научное направление - магнитный структурно-фазовый анализ сталей и сплавов.

Рост технического уровня и необходимость повышения конкурентоспособности продукции машиностроения увеличили потребность в применении средств неразрушающего контроля (НК) для оценки ее качества. Чем позднее от начала процесса производства находится момент обнаружения брака, тем более дорогим становится его исправление, тем выше себестоимость продукции. В настоящее время в металлургических и машиностроительных отраслях промышленности при хорошей организации контроля затраты на неустранимый брак составляют 2-4 \% от себестоимости продукции, при плохой - $15 \%$ и более. Значительное место в неразрушающем определении структуры, фазового состава физикомеханических свойств и других эксплуатационных характеристик изделий металлургической и машиностроительной промышленности принадлежит магнитным методам.

Схематически возможности использования магнитных методов неразрушающего контроля структуры и фазового состава можно изобразить в виде некоего «дерева» (рис. 2), корнями которого являются физическое материаловедение, физика магнитных явлений, механика деформируемого твердого тела и научное приборостроение, ветви соответствуют определенным направлениям контроля, а листья - методам и способам контроля.

Различные фазы и структуры имеют различные механические, магнитные, электрические и другие характеристики. Изменение структуры и фазового состава влечет за собой изменение большинства физических свойств и прочностных характеристик материала. Одной из основных задач неразрушающего структурно-фазового анализа является познание характера этих связей. Когда они будут познаны, откроется возможность для решения обратных задач - по известным физическим свойствам или прочностным характеристикам определять фазовый состав (количество определенной фазы) материала и его структуру.

Связь фазового состава и структуры с прочностными характеристиками изучена давно, поэтому в промышленности очень часто структура и фазовый состав оцениваются по каким-либо прочностным характеристикам. Из изложенного выше следует, что для оценки структуры и фазового состава могут быть использованы и многие физические характеристики и соответственно методы контроля. Действительно, для оценки структурно-фазового состояния материала применяют ультразвуковые, магнитные, электрические, тепловые и рентгеновские методы.

Gorkunov E. S. / Magnetic structural-phase analysis as applied to diagnosing and evaluating the lifetime of products and structural components. Part 1 
opent-aceess journal

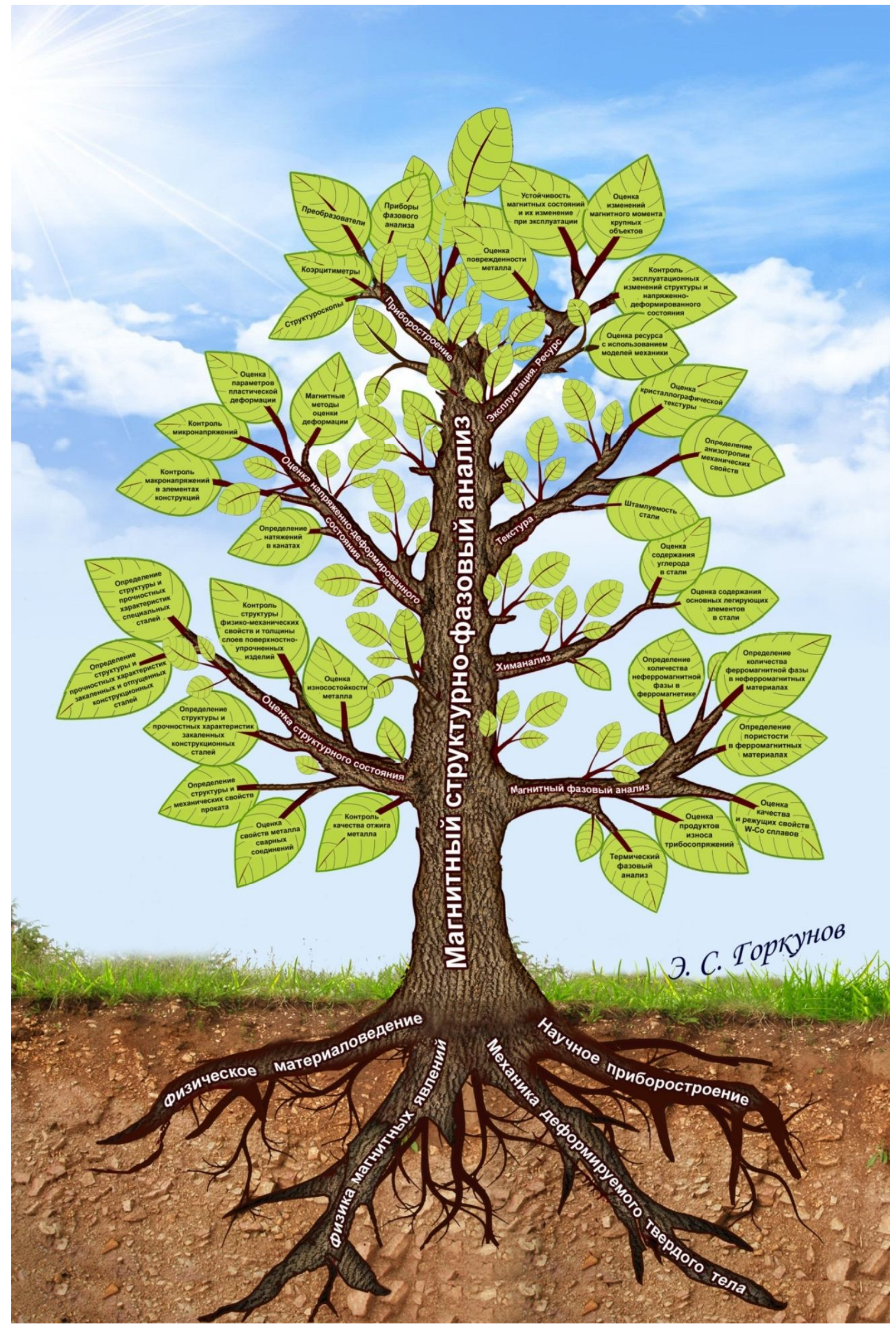

Рис. 2. Схематическое дерево магнитного структурного фазового анализа 
На практике при конструировании машин, сооружений и другой техники при расчетах используют прочностные или специальные характеристики, поэтому чаще всего неразрушающие физические методы применяют для оценки именно этих свойств на основе ранее установленных корреляционных связей.

К выбору физического параметра контроля предъявляется ряд требований:

- он должен быть чувствителен к изменениям структуры или фазового состава (в зависимости от того, что контролируется);

- измерение должно быть экспрессным и желательно бесконтактным;

- $\quad$ он должен быть устойчивым к влиянию внешних мешающих факторов (например, к зазору между преобразователем и изделием, колебанию температуры окружающей среды, индустриальным помехам) и т.д.;

- $\quad$ он должен позволять проводить измерения на изделиях любой формы и размеров.

Достаточно хорошо этим требованиям соответствуют магнитные методы. Рис. 3 иллюстрирует существующие связи между первичными и вторичными свойствами ферромагнитного металла и установленными корреляционными связями между ними.

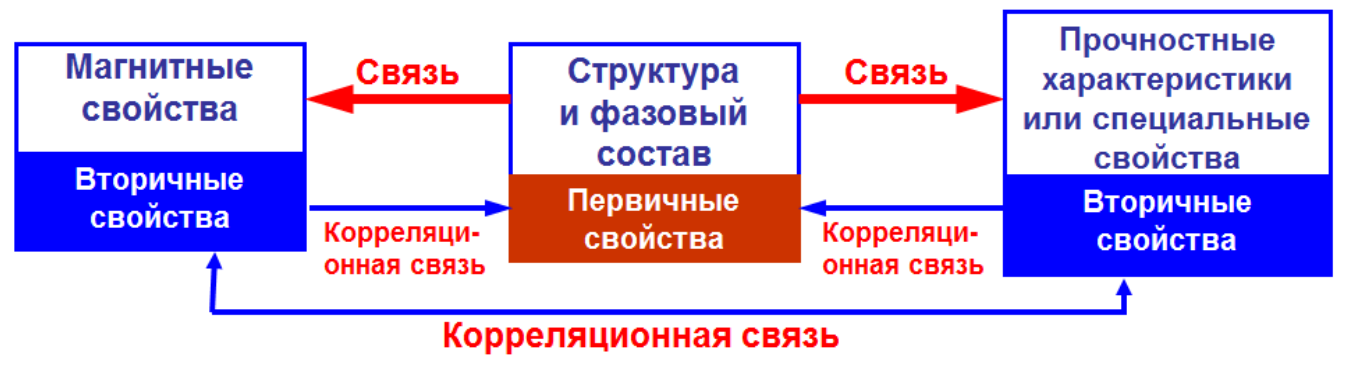

Рис. 3. Взаимосвязи структурного состояния и фазового состава с физическими и прочностными свойствами материала

Таким образом, в современном машиностроении и металлургии методы структурнофазового магнитного анализа используются для решения ряда проблем, каждая из которых в свою очередь позволяет решать изложенные ниже задачи [2-4].

\section{2. Оценка структурного состояния}

\section{1 Определение размера зерна в сталях}

Наглядно влияние структурных факторов на процессы перемагничивания можно проследить на примере доменной структуры в поликристаллических ферромагнетиках. Величина зерен и их разориентация оказывают определенное влияние на магнитную доменную структуру, подвижность доменных границ и, соответственно, на многие магнитные характеристики, в том числе на отдельные акты необратимого изменения намагниченности - скачки Баркгаузена. Теоретические и экспериментальные исследования зависимости между средним размером зерна ферромагнитной стали и магнитными характеристиками материала (коэрцитивная сила, параметры доменной структуры, информационные параметры эффекта Баркгаузена и др.) стали классическими задачами физики магнитных явлений и магнитной структуроскопии.

В общем случае ширина и длина магнитных доменов определяются размерами зерен поликристалла. Рис. 4 иллюстрирует типичную разнозернистую макроструктуру поликристалла сплава $\mathrm{Fe}-3$ \% Si, ориентация зерен которого характеризуется кристаллографической текстурой типа $\{110\}<100>$. Можно видеть, что большему среднему размеру зерна соответствует и бо́льшая ширина его полосовых $180^{\circ}$-х доменов. 
Границы зерен являются препятствиями для смещающихся доменных границ. Таким образом, увеличение размеров зерна (уменьшение протяженности границ в ферромагнетике) должно сопровождаться снижением величины коэрцитивной силы.

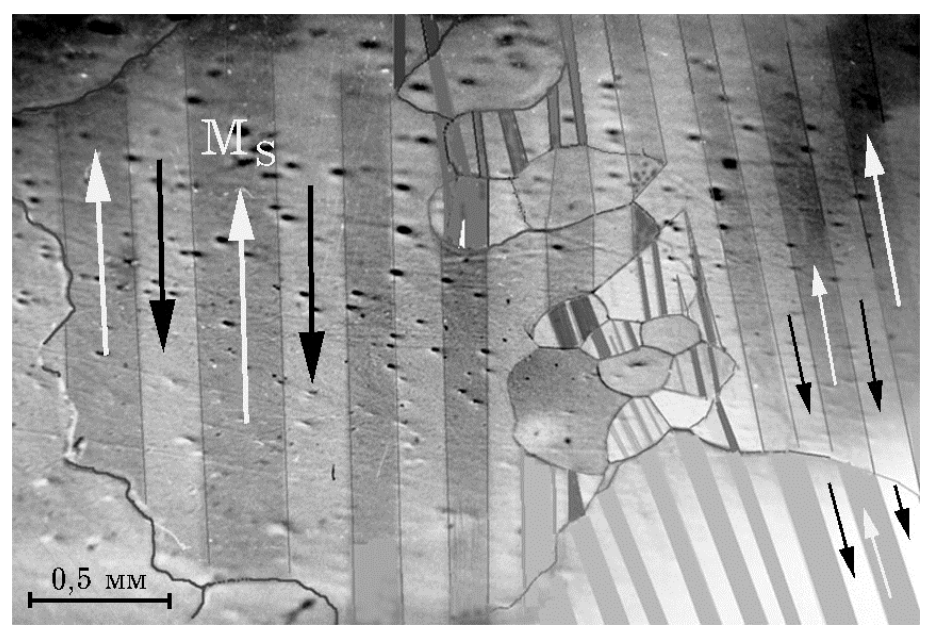

Рис. 4. Вид доменной структуры в поликристалле кремнистого железа с многокомпонентной кристаллографической структурой

По данным [5], для железа различной степени чистоты было получено эмпирическое уравнение, связывающее коэрцитивную силу $H_{c}$ со средним размером зерна $d_{3}$ :

$$
H_{\mathrm{c}}=A / d_{3}+B \text {, }
$$

в котором коэффициенты $A$ и $B$ зависят от степени легирования и количества примесей в железе $\left(d_{3}\right.$ измеряется в см). Для чистого железа $A=0,0018, B=0$ [5], а для электролитического железа, содержащего 0,024\% углерода, $A=0,0032, B=0,32$ [6]. Рис. 5 иллюстрирует зависимость коэрцитивной силы от величины зерна для чистого железа и низкоуглеродистой стали.
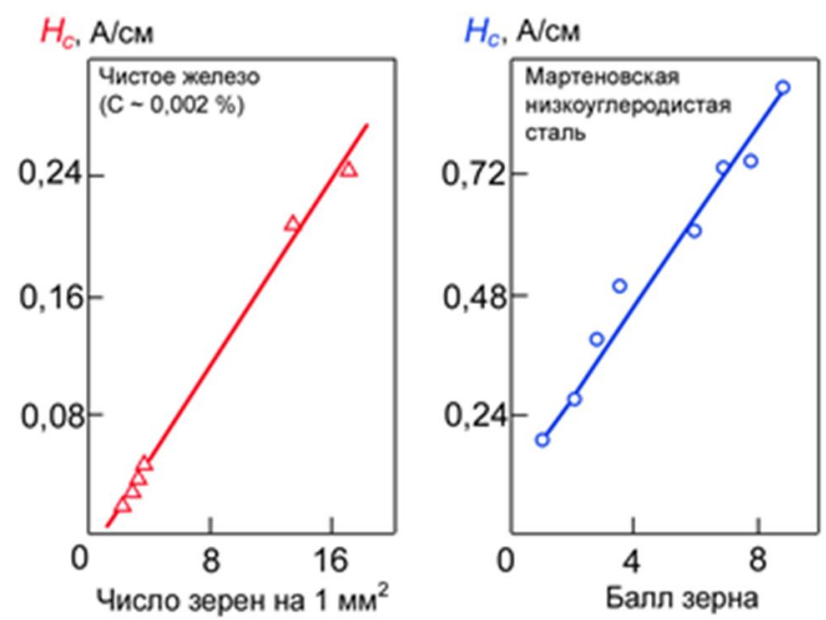

Рис. 5. Взаимосвязь коэрцитивной силы с величиной зерна для чистого железа (C 0,002 \%) [5] и для мартеновской низкоуглеродистой стали [7] 
2.2 Определение структурного состояния и механических свойств холодно- и горячекатаного проката как на заводах-изготовителях, так и на заводах-потребителях при определении качества поступающеего металла (входной контроль)

Конкретная структура металла при прокатке формируется под действием следующих процессов: температуры и времени выдержки металла при этой температуре перед прокаткой, температуры конца прокатки ( $\left.T_{\text {Кп }}\right)$ и степени обжатия при прокатке $\varepsilon$.

Перед горячей прокаткой необходим высокотемпературный нагрев слябов (обычно $\left.1220 \ldots 1280{ }^{\circ} \mathrm{C}\right)$. Температура конца прокатки зависит от размеров слябов и заданных размеров листа. Например, согласно [8] увеличение толщины листа с 12,7 до 50 мм при постоян-

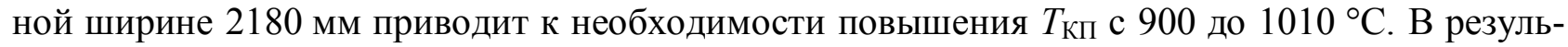
тате это повышение $T_{\text {Кп }}$ сопровождается снижением предела текучести $\sigma_{\mathrm{T}}$ и повышением критической температуры хрупкости. Поэтому для получения оптимальных свойств листов в последние годы используется регулируемая и контролируемая прокатка.

После горячей прокатки размер ферритного зерна в стали обычно меньше, чем

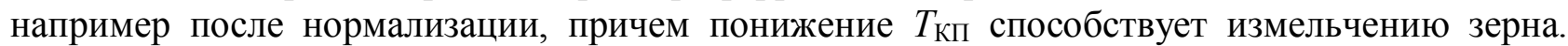
При этом добиваются, чтобы режим прокатки обеспечивал оптимальное сочетание измельчения зерна с возможным дисперсионным твердением. Здесь следует учитывать два фактора: скорость динамической рекристаллизации, которая увеличивается при повышении температуры и степени деформации (может снижаться под влиянием растворённых атомов или выделений второй фазы); скорость укрупнения зерна, увеличивающаяся при повышении температуры (может уменьшаться частицами второй фазы) [8-12].

В углеродистых сталях при температурах прокатки выше $800{ }^{\circ} \mathrm{C}$ рекристаллизация происходит практически сразу, но существенно замедляется при температурах ниже $800{ }^{\circ} \mathrm{C}$, когда полной рекристаллизации предшествует образование феррита [12]. Измельчению ферритного зерна способствует мелкое аустенитное зерно, поэтому важно правильно выбрать

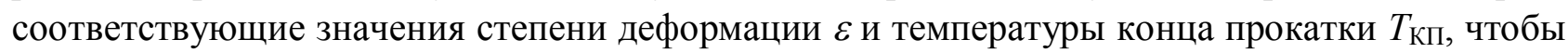
обеспечить формирование мелкого рекристаллизованного аустенитного зерна. Большие зна-

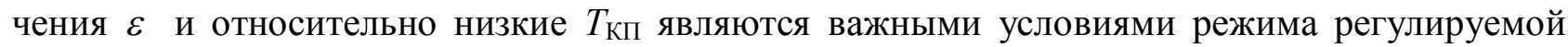

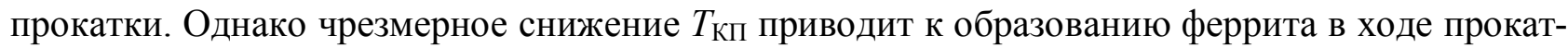
ки, его последующей деформации и к тому, что процессы возврата и рекристаллизации проходят не полностью. Это также вызывает рост критической температуры хрупкости [13].

На рис. 6 представлены зависимости от температуры конца прокатки значений коэрцитивной силы $H_{\mathrm{c}}$, максимальной магнитной проницаемости $\mu_{\max }$ и остаточной магнитной индукции $B_{\mathrm{r}}$, а также временного сопротивления при разрыве $\sigma_{\mathrm{B}}$, предела текучести $\sigma_{\mathrm{T}}$, относительного удлинения $\delta_{5}$, соответствующие различным степеням обжатия при прокатке, а на рис. 7 - аналогичные зависимости ударной вязкости $K C U^{-20}$ и $K C U^{20}$ и твёрдости $H R B$.

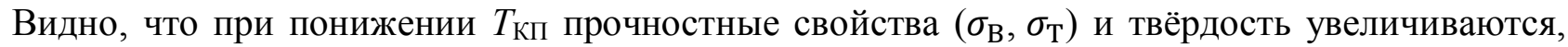

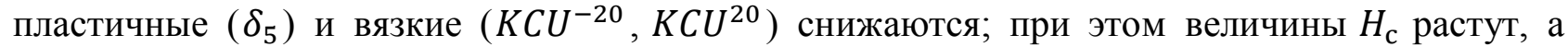
$\mu_{\max }$ - убывают.

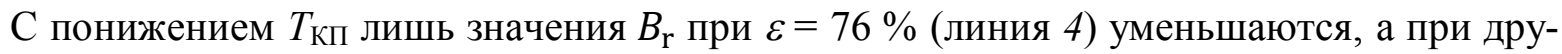
гих степенях обжатия проходят через минимум. Температура конца прокатки, при которой проявляется этот минимум, зависит от степени деформации: чем ниже значения $\varepsilon$, тем выше

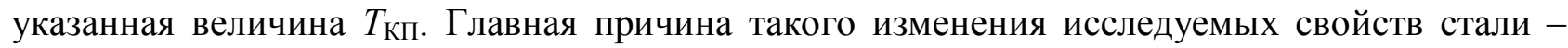
измельчение ферритного зерна и неполная рекристаллизация. Завершение пластической деформации при температурах $850 \ldots 800{ }^{\circ} \mathrm{C}$ приводит к измельчению зерна аустенита и некоторому торможению его роста дисперсными частицами нитридов и карбонитридов, выделяю-

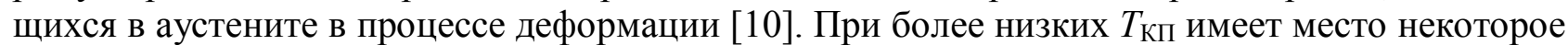
укрупнение зерна.

При высоких степенях обжатия ( $\varepsilon=60 \%$ характерно постепенное изменение формы зерна от равноосной (при $\left.T_{\text {Кп }}=1050{ }^{\circ} \mathrm{C}\right)$ до игольчатой $\left(T_{\text {Кп }}=800{ }^{\circ} \mathrm{C}\right)$, а при низких $T_{\text {Кп }}$ 
наблюдается видманштеттова структура. Как уже упоминалось, образованию видманштеттовой структуры в сталях способствует крупное аустенитное зерно. Для образцов, прокатанных с обжатием $76 \%$, она может быть обусловлена ещё повторным нагревом листов для последующей прокатки от 20 до 12 мм и их быстрым (вследствие малой толщины) охлаждением после прокатки в критическом интервале температур. С увеличением степени обжатия общий уровень прочностных характеристик, твёрдости и коэрцитивной силы возрастает, а относительного удлинения, ударной вязкости и максимальной магнитной проницаемости уменьшается.
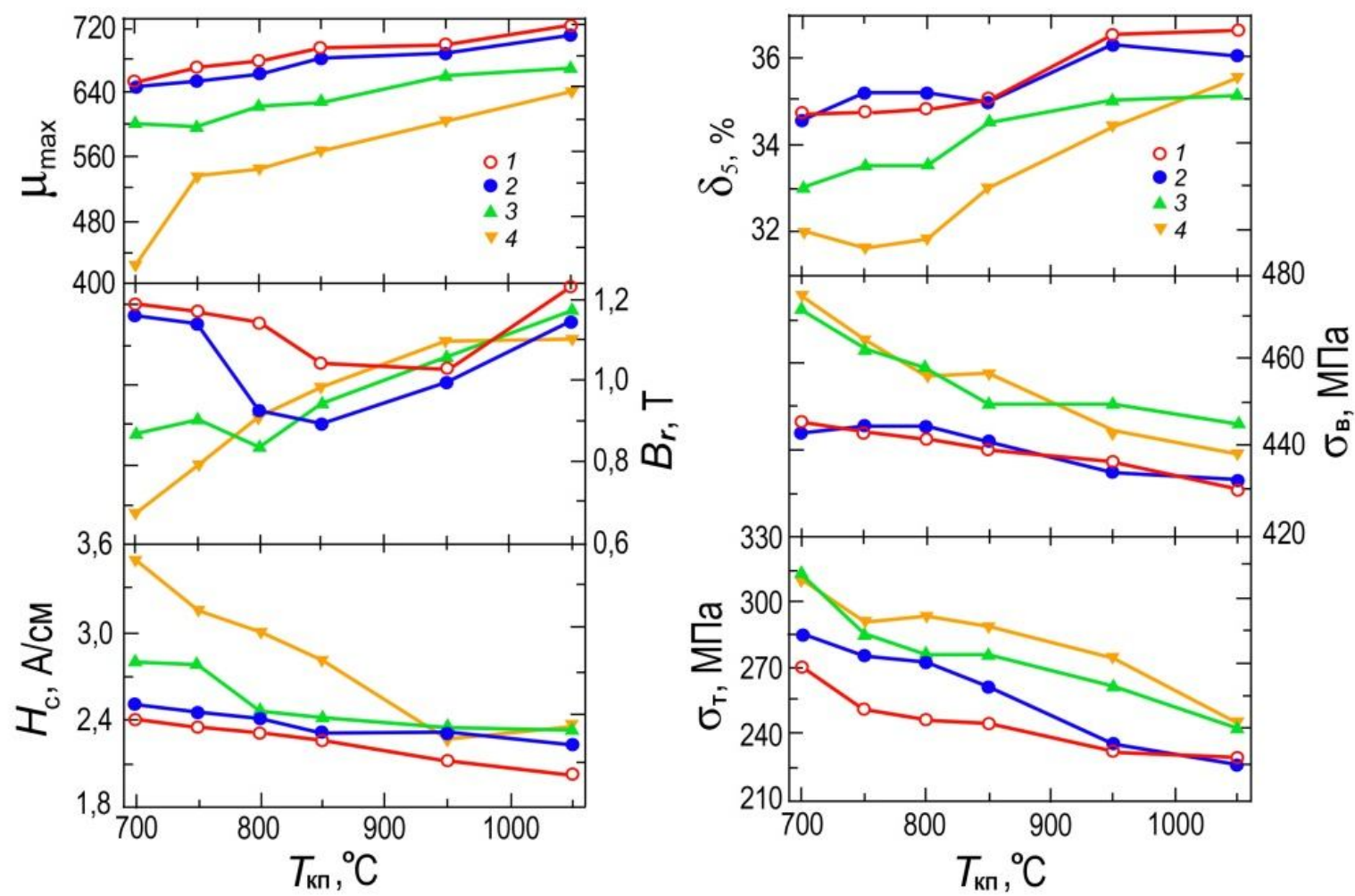

Рис. 6. Зависимость механических $\left(\sigma_{\mathrm{B}}, \sigma_{\mathrm{T}}, \delta_{5}\right)$ и магнитных $\left(H_{\mathrm{c}}, B_{\mathrm{r}}, \mu_{\mathrm{max}}\right)$ свойств стали Ст.Зсп от температуры конца прокатки при различных степенях обжатия:

$$
1-20,2-40,3-60,4-76 \%
$$

Наблюдаемое относительное изменение физических свойств (рис. 6 и 7), вызванное

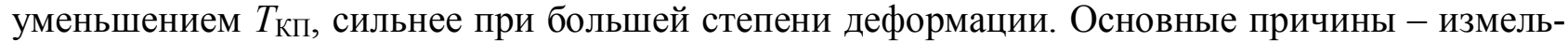
чение ферритного зерна и увеличение степени его игольчатости. У образцов, деформированных на $40 \%$ (кривая 2) и $60 \%$ (кривая 3), имеет место увеличение балла полосчатости, а при $\varepsilon=76 \%$ (кривая 4) - в основном изменение формы феррита от равноосной до видман-

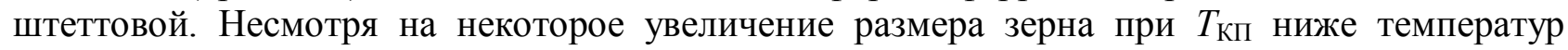
аустенитного превращения, коэрцитивная сила всё же продолжает возрастать, что, повидимому, обусловлено увеличением внутренних напряжений в феррите вследствие неполной рекристаллизации.

Понижение температуры конца прокатки (до $800{ }^{\circ} \mathrm{C}, \varepsilon=60 \%$ (3), $850{ }^{\circ} \mathrm{C}, \varepsilon=40 \%$ (2) и $\left.950{ }^{\circ} \mathrm{C}, \varepsilon=20 \%(1)\right)$ сопровождается уменьшением остаточной магнитной индукции $B_{\mathrm{r}}$,

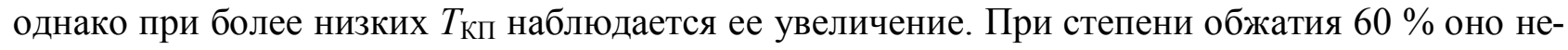
значительно, а при $\varepsilon=76$ \% (4) полностью отсутствует. При малых и средних степенях обжатия $B_{\mathrm{r}}$ определяется преимущественно размером зерна феррита (влияние формы зерна здесь

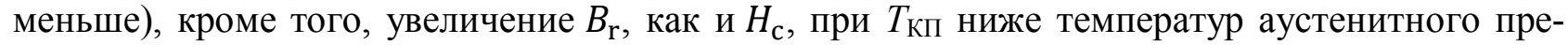
вращения обусловлено увеличением внутренних напряжений. При $\varepsilon=76$ \% фактор формы 
зерна решающий: размер зерна здесь примерно один и тот же - 7 баллов по ГОСТ 5639-82. Низкая остаточная магнитная индукция при температурах конца прокатки 750 и $700{ }^{\circ} \mathrm{C}$ здесь связана с наличием видманштеттовой структуры. Некоторый вклад в уменьшение величины $B_{\mathrm{r}}$ вносит и наблюдаемая полосчатость. Уменьшение $B_{\mathrm{r}}$ вследствие измельчения структуры обусловлено увеличением внутренних размагничивающих полей кристаллитов $[14,15]$; рост игольчатости в форме феррита и появление видманштеттовой структуры приводит к повышению внутренних напряжений.

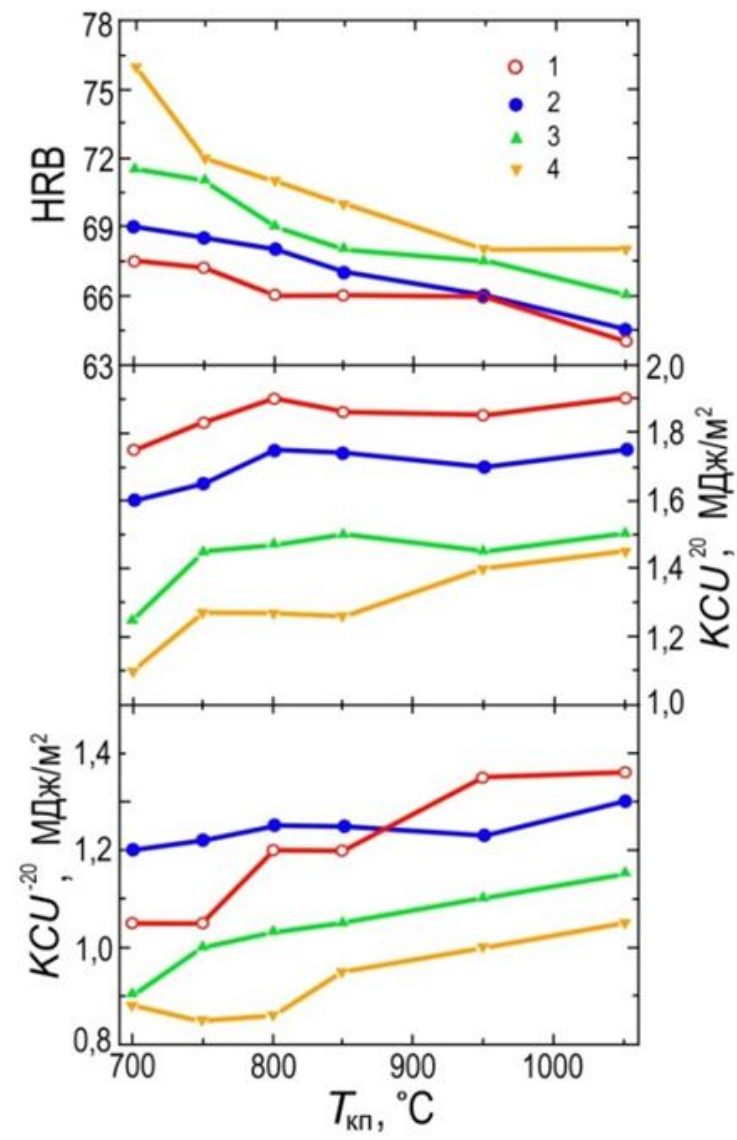

Рис. 7. Зависимость ударной вязкости при -20 и $20^{\circ} \mathrm{C}$, а также твердости от температуры конца прокатки при различной степени обжатия. Обозначения см. на рис 6

\section{3 Контроль структурного состояния и прочностных характеристик термически об- работанных стальных изделий (отюсиг, нормализация) [16, 17]}

У низкоуглеродистых сталей с повышением температуры отжига до $400{ }^{\circ} \mathrm{C}$ механические свойства изменяются незначительно (рис. 8), так как в этом интервале особых структурных изменений не наблюдается. Небольшое уменьшение внутренних напряжений в металле вызывает некоторые снижения коэрцитивной силы $H_{\mathrm{c}}$ и остаточной индукции $B_{\mathrm{r}}$. Основные изменения магнитных и механических свойств низкоуглеродистых сталей происходят в интервале температур 500-600 ${ }^{\circ} \mathrm{C}$ (см. рис. 8), что объясняется уменьшением микронапряжений, изменением величины зерен и их ориентации, т.е. рекристаллизационными процессами. При дальнейшем повышении температуры отжига продолжается рост зерна (вторичная рекристаллизация), что сопровождается увеличением магнитной проницаемости, уменьшением коэрцитивной силы и остаточной индукции, твердости и предела прочности. Это указывает на возможность оценки механических свойств сталей по измерениям максимальной и начальной магнитных проницаемостей, коэрцитивной силы и остаточной индук- 
ции. Использование последних двух характеристик предпочтительнее, так как они наиболее просты в измерении и менее подвержены влиянию мешающих факторов. Наибольший интерес представляют интервалы температур 580-700 ${ }^{\circ} \mathrm{C}$ или $680-750{ }^{\circ} \mathrm{C}$, в которых осуществляется отжиг указанных сталей.

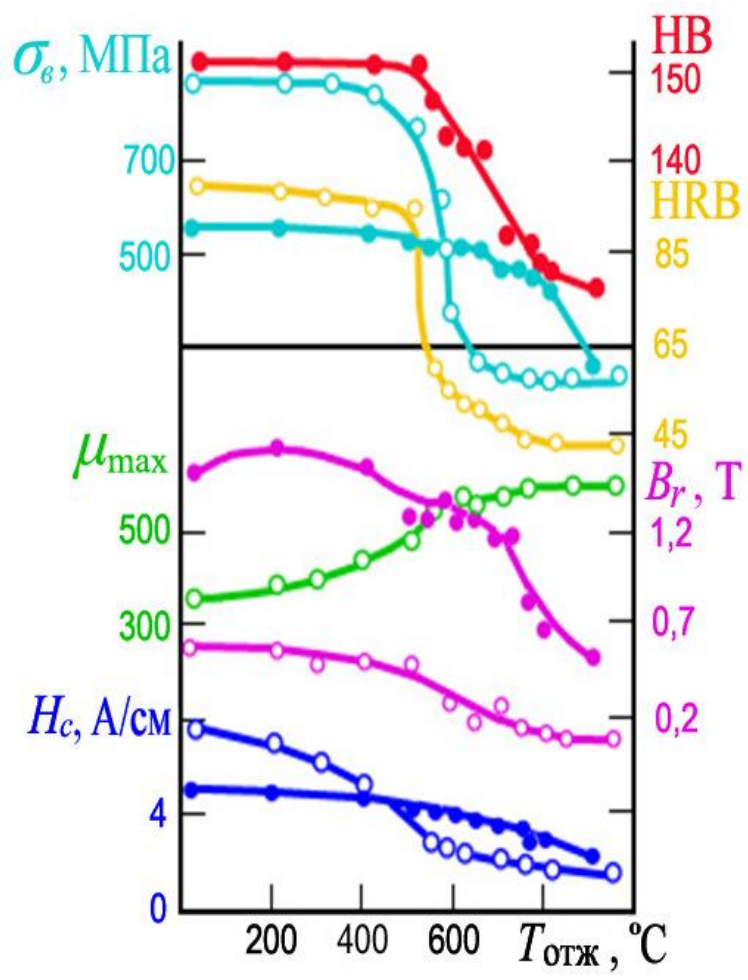

Рис. 8. Физико-механические свойства холоднокатаной 08Ю (о) и горячекатаной 30Т $(\bullet)$ сталей в зависимости от температуры отжига

В технологическом интервале температур отжига изменения магнитных и механических свойств, как правило, невелики. Кроме того, на магнитные и механические характеристики сталей могут влиять колебания химического состава в пределах допуска, значения температуры конца прокатки и степень обжатия, а также температуры отжига, за счет изменения величины и формы зерна и другие факторы. Поэтому широкому внедрению магнитных методов контроля качества отжига низкоуглеродистых сталей предшествуют исследования по установлению корреляционных связей между магнитными, например $H_{c}$, и контролируемыми (чаще всего механическими) параметрами, а также оценка влияния на них различных технологических факторов, определяющих истинный коэффициент этой связи для данных условий производства проката. При внедрении магнитных методов контроля для учета конкретных особенностей технологического процесса на предприятии проводятся набор и обработка статистических данных. Для каждого типоразмера проката и марки стали по уравнениям регрессии рассчитывают значения контролируемых параметров (предела текучести, временного сопротивления, относительного удлинения) в целях построения градуировочных кривых или таблиц соответствия между показаниями приборов и механическими свойствами.

Внедрение магнитных методов НК механических свойств проката позволяет решить задачу отбраковки некачественной продукции. Однако возможны варианты использования информации, получаемой от средств НК, для определения алгоритмов активного управления качеством проката и выбора критериев оптимизации технологического процесса изготовления проката. 
При отжиге для снятия остаточных напряжений установить снижение уровня напряжений возможно по измерению магнитных свойств. Согласно теории, учитывающей влияние напряжений в ферромагнетике на величину коэрцитивной силы, изменение уровня внутренних микронапряжений вызывает изменение величины коэрцитивной силы, что позволяет осуществлять надежный контроль качества отжига изделий коэрцитиметрическими методами.

Ярким примером применения магнитных методов является контроль сфероидизирующего отжига подшипниковых сталей. Измерения магнитных свойств на изделиях с различной структурой показали, что величины коэрцитивной силы структур с зернистым и пластинчатым перлитом сильно различаются. Возможность применения коэрцитиметрических методов для контроля отожженных структур иллюстрирует рис. 9.

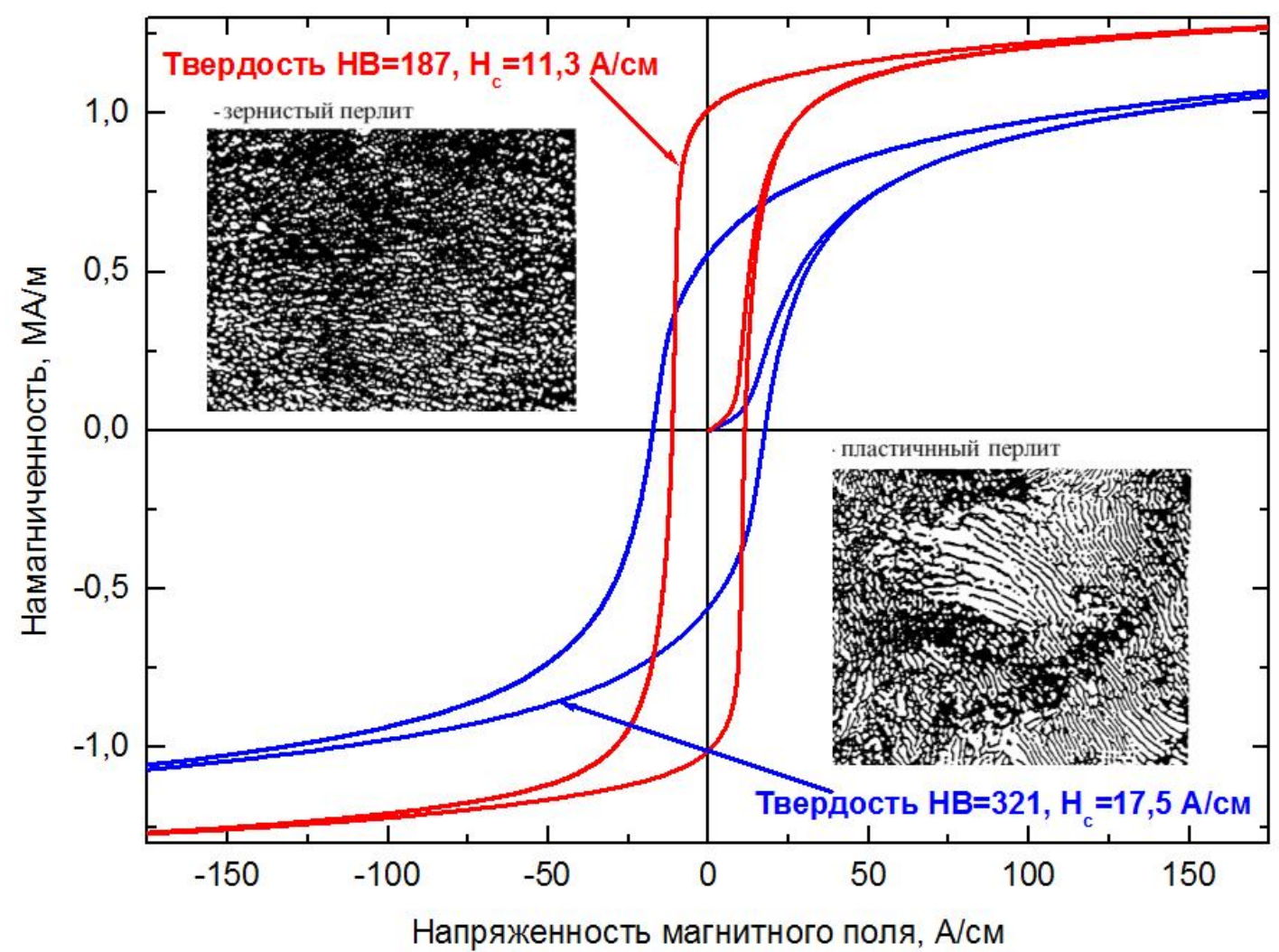

Рис. 9. Петли гистерезиса и микроструктура подшипниковой стали ШХ15

Годными считаются изделия с твердостью 180-207 HВ, что может быть выявлено путем измерения с помощью коэрцитиметра. Некондиционные структуры отжига стали ШХ15 обладают высокой твердостью и влекут за собой большой износ режущего инструмента, а при последующей термической обработке приводят к образованию структур крупноигольчатого мартенсита, для которых характерно образование поверхностных трещин. Например, ресурс работы подшипника с такой структурой металла будет весьма ограниченным. Некондиционные структуры пластинчатого перлита могут быть отбракованы по коэрцитивной силе.

\section{4 Определение структуры и прочностных характеристик закаленных конструкцион- ных сталей [2, 3, 18-32]}

Закалка - это процесс термической обработки, состоящий в нагреве до температур в интервале $\alpha \rightarrow \gamma$-превращений и выше, выдержке при этих температурах и последующем охлаждении со скоростью выше критической. Результатом закалки является получение неравновесных структур мартенсита, а также продуктов распада аустенита по промежуточной ступени - бейнита и тростита.

Gorkunov E. S. / Magnetic structural-phase analysis as applied to diagnosing and evaluating the lifetime of products and structural components. Part 1 
Появление при закалке в структуре стали мартенсита сопровождается увеличением эффективной магнитной анизотропии (“магнитной жесткости”), обусловленной тетрагональностью решетки мартенсита, повышением плотности дислокаций и уровня микронапряжений.

Образование в доэвтектоидной стали мартенситной структуры приводит к повышению магнитной жесткости стали; при этом площадь петель магнитного гистерезиса существенно возрастает, а коэрцитивная сила увеличивается более чем в 2 раза. Намагниченность насыщения $M_{\mathrm{S}}$ отражает изменения, происходящие в фазовом составе стали. Снижение $M_{\mathrm{S}}$ в интервале температур $725-800{ }^{\circ} \mathrm{C}$ связано с появлением в структуре закаленной стали остаточного аустенита. Удельное электросопротивление $\rho$ с повышением температуры закалки до $800-850^{\circ} \mathrm{C}$ растет, что связано с увеличением содержания углерода в пересыщенном твердом растворе и появлением некоторого количества остаточного аустенита. Закалка доэвтектоидных сталей от температур 800-850 ${ }^{\circ} \mathrm{C}$ и выше не приводит к изменению магнитных и электрических свойств стали 30ХГСА и $602 \mathrm{~A}$ (рис. $10 \mathrm{a}$, г). Это связано с тем, что при таких температурах закалки практически весь углерод переходит в твердый раствор, параметры решетки мартенсита стабилизируются, микронапряжения и плотность дислокаций достигают максимальной величины, следовательно, величина наведенной эффективной магнитной анизотропии становится постоянной.

Эвтектоидные стали имеют общие закономерности изменения магнитных и электрических свойств с доэвтектоидными сталями при низкой температуре аустенизации, в то же время в области температур перегрева при закалке для заэвтектоидных сталей наблюдается некоторое их различие, заключающееся в неоднозначном изменении коэрцитивной силы от температуры закалки (рис. 10в). Величина максимума коэрцитивной силы зависит от содержания углерода в стали ШХ15, а его природа обусловлена изменениями относительного объема и дисперсности включений остаточного аустенита и избыточных карбидов. Максимум коэрцитивной силы соответствует примерно 12 \% содержания остаточного аустенита в стали.

Характер изменения электросопротивления и намагниченности насыщения в зависимости от температуры закалки определяется количеством углерода в стали, поскольку с повышением содержания углерода в ней образуется большее количество остаточного аустенита вследствие снижения точек начала мартенситного превращения. Удельное электросопротивление, величина которого в значительной степени зависит от содержания в стали остаточного аустенита, с повышением температуры закалки растет.

Из исследований $[2,3,18-32]$ и рис. 10 следует, что структуры и прочностные характеристики, соответствующие низкой температуре аустенизации (недогрев при закалке), могут быть выявлены по любой магнитной характеристике. Таким образом, после предварительной градуировки прибора можно производить оценку прочностных характеристик изделий из доэвтектоидных сталей. Перегрев доэвтектоидных сталей нельзя выявить по магнитным и механическим характеристикам, но необходимости в этом нет, поскольку доэвтектоидные стали имеют низкую склонность к “перегреву” при закалке. При контроле качества закалки этой группы сталей широкое распространение получили коэрцитиметры $[2,3,18]$.

Заэвтектоидные и легированные стали ШХ15 и 20X13 чувствительны к “перегреву”, поэтому для них актуальна проблема разработки методов контроля как "недогрева", так и “перегрева". Для выявления при закалке брака от “недогрева" и “перегрева" предложено использовать два параметра: коэрцитивную силу и намагниченность насыщения. Высокие значения намагниченности насыщения и низкие значения коэрцитивной силы свидетельствуют о "недогреве", пониженные значения $H_{\mathrm{c}}$ и низкие значения $M_{\mathrm{S}}$ - о “перегреве".

Двухпараметровый метод, реализованный в дифференциальных магнитных структуроскопах различных моделей [2, 3, 35-38], хорошо зарекомендовал себя при контроле качества закалки деталей из высокоуглеродистых и инструментальных сталей, но наиболее массово он применяется в подшипниковой промышленности. Одновременно с контролем каче- 
open-2CCess journal

ства закалки данная методика позволяет по измерениям величины намагниченности насыщения определить и количество остаточного аустенита в стали $[2-4,20,35]$, что очень важно для высокоточных изделий.

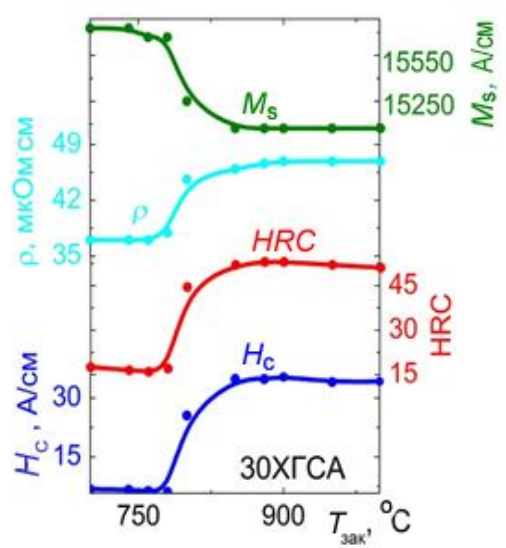

$a$

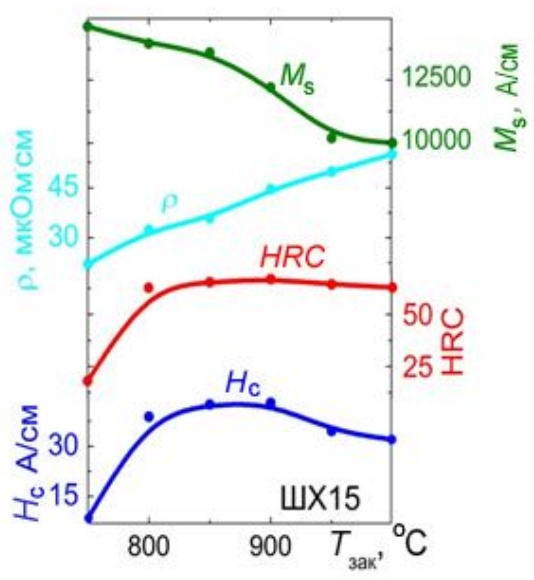

B

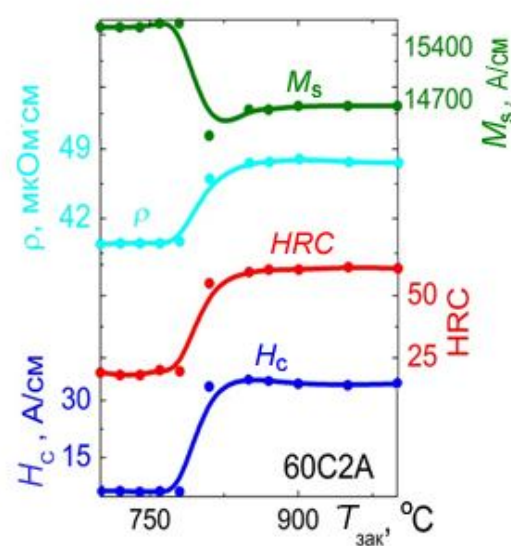

6

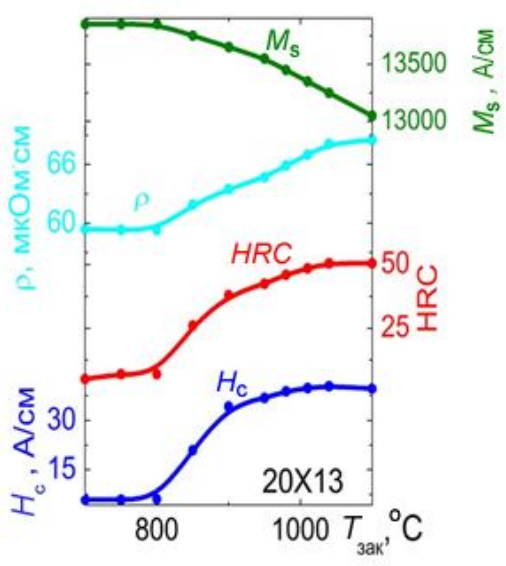

2

Рис. 10. Свойства закаленных сталей: $H_{\mathrm{c}}$ - коэрцитивная сила; HRC - твердость; $\rho$ - удельное электросопротивление; $M_{\mathrm{S}}$ - намагниченность насыщения.

$$
a \text { - сталь } 30 \text { ХГСА, } \sigma-60 \mathrm{C} 2 \mathrm{~A}, \text {, } в-\text { ШХ15, } 2-20 \mathrm{X} 13
$$

\section{5 Определение структуры и прочностных характеристик закаленных и отпущенных конструкционных сталей $[2,3,18-34]$}

Для конструкционных сталей с содержанием углерода до 0,3 \% характерно монотонное изменение большинства физических свойств и прочностных характеристик в интервале температур отпуска от комнатных до $650{ }^{\circ} \mathrm{C}$ (рис. $11 a$ ). Монотонное изменение магнитных характеристик с температурой отпуска, связанное с выделением углерода из твердого раствора, распадом аустенита и снижением уровня микронапряжений, позволяет использовать их для неразрушающего определения структурного состояния и контроля прочностных свойств изделий, отпущенных в интервале температур $150-650{ }^{\circ} \mathrm{C}$.

Для конструкционных сталей с содержанием углерода 0,3 \% и более изменения магнитных свойств в интервале высоких температур отпуска не монотонны (рис. 11б). Поскольку большое количество сталей различных классов, которые широко используются в современном машиностроении при изготовлении отдельных деталей, узлов и механизмов, содержат, как правило, более 0,3 \% углерода, то существует проблема контроля деталей из этих сталей. Неоднозначное изменение с температурой отпуска большинства широко распростра- 
opter-access jürnal

ненных в практике НК магнитных характеристик делает невозможным их использование для контроля средне- и высокотемпературного отпуска изделий из сталей этой группы.
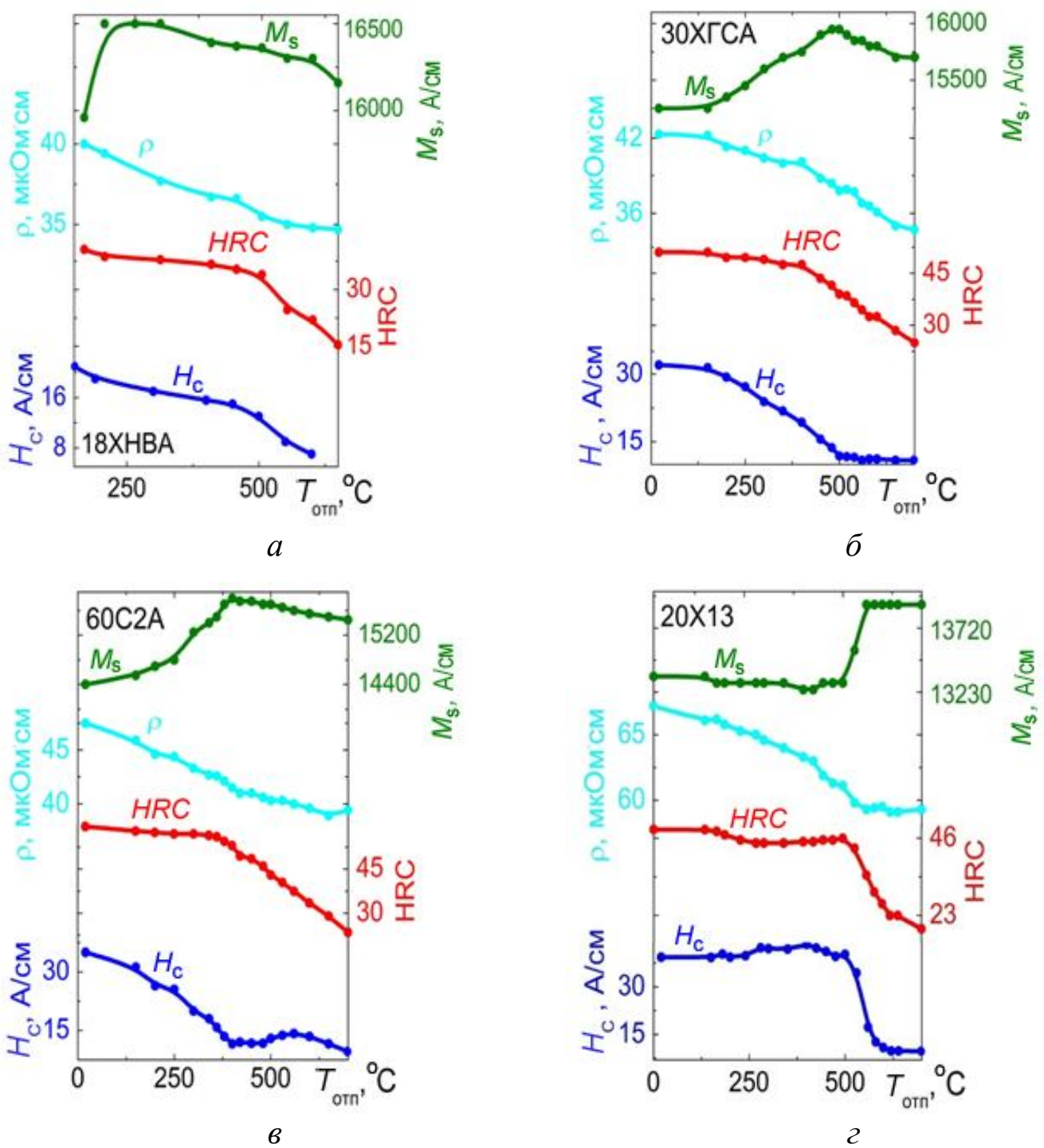

Рис. 11. Свойства отпущенных сталей: $H_{\mathrm{c}}$ - коэрцитивная сила; НRC - твердость; $\rho$ - удельное электросопротивление; $M_{\mathrm{S}}$ - намагниченность насыщения; $a$ - сталь 18 ХНВА, $\sigma-30$ ХГСА, $, 6-60 \mathrm{C} 2 \mathrm{~A}, 2-20 \mathrm{X} 13$

Новый подход к решению проблемы контроля качества отпущенных изделий из сталей этой группы, а также к оценке деградации эксплуатационных свойств изделий дает изучение явлений устойчивости магнитных состояний ферромагнетиков к внешним воздействиям (магнитных и электромагнитных полей, упругих и пластических деформаций и температуры) $[33,34,39,40]$. Исследования устойчивости магнитных состояний, кинетики (динамики) изменения магнитных характеристик при различных воздействиях позволяют получить отличную от других методов информацию о структурном состоянии и фазовом составе стали, а также перейти от выявления факта возникновения брака изделий, например при термической обработке, к непосредственной корректировке технологического процесса изготовления деталей или прогнозированию изменения физико-механических свойств изделий в процессе эксплуатации. 


\section{6 Определение структуры и прочностных характеристик специальных сталей}

Мартенситно-стареющие стали. Упрочнение мартенситно-стареющих сплавов связано с начальными стадиями образования интерметаллидных фаз при старении. Предполагают [41-43], что выделению стабильных фаз предшествует так называемая зонная стадия распада твердого раствора (образование зон Гинье-Престона или сегрегации, обогащенных атомами легирующих элементов, которые служат зародышами выделяющейся фазы) и образование промежуточных фаз, когерентно или полукогерентно связанных с матрицей. Повышение прочностных характеристик (рис. 12, кривые HRC) при температурах старения 300$450{ }^{\circ} \mathrm{C}$ связывают с зонной стадией распада твердого раствора, так как никаких изменений в структуре кристаллов мартенсита не наблюдается. По данным работы [42], в большинстве железоникелевых сплавов происходит лишь незначительное уменьшение плотности дислокаций. Образующиеся сегрегации атомов легирующих элементов имеют размеры, не превышающие 0,004-0,006 мкм. В исследованных сталях, по-видимому, как и в железоникелевых сплавах с $18 \% \mathrm{Ni}$, легированных молибденом и титаном, на стадии максимального упрочнения $\left(480-500^{\circ} \mathrm{C}\right)$ и в перестаренном состоянии присутствуют частицы $\mathrm{Fe}_{2} \mathrm{Mo}, \mathrm{Ni}_{3} \mathrm{Mo}$ и $\mathrm{Ni}_{3} \mathrm{Ti}$.

Магнитные свойства в интервале температур 20-500 ${ }^{\circ} \mathrm{C}$ практически не меняются (см. рис. 12). Незначительное снижение коэрцитивной силы в диапазоне $300-400{ }^{\circ} \mathrm{C}$ объясняется уменьшением плотности дислокаций и величины микронапряжений в мартенсите. При температурах старения $400-500{ }^{\circ} \mathrm{C}$ уменьшение $H_{\mathrm{c}}$ за счет отмеченных факторов компенсируется ее ростом вследствие образования промежуточных интерметаллидных фаз.

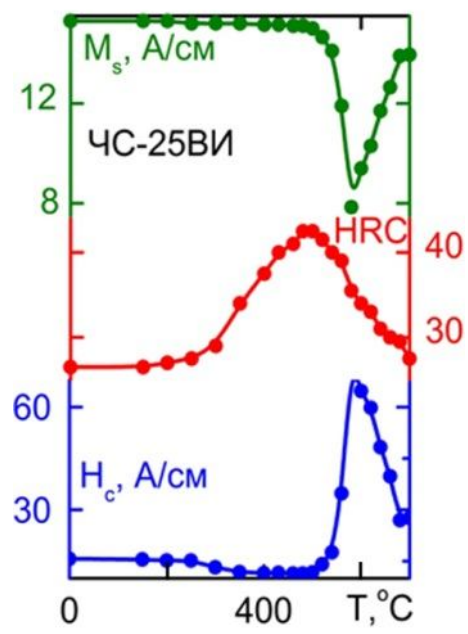

Рис. 12. Зависимость физико-механических свойств мартенситно-стареющей стали ЧС-25ВИ, закаленной от $820^{\circ} \mathrm{C}$ на воздухе, от температуры отпуска (старения).

Время выдержки при отпуске 3 ч

Разупрочнение исследованных сталей при температурах старения, превышающих $500{ }^{\circ} \mathrm{C}$, определяется протеканием нескольких процессов: коагуляцией частиц, образованием стабилизированного аустенита и "свежего" мартенсита [41]. Поведение изученных физических свойств при температурах старения, превышающих $500{ }^{\circ} \mathrm{C}$, в основном связано с образованием аустенита, обогащенного никелем. Максимальное количество стабилизированного аустенита в структуре состаренных сталей образуется при $T_{\text {отп }}=580{ }^{\circ} \mathrm{C}$, что приводит к уменьшению намагниченности насыщения и повышению коэрцитивной силы в интервале 500-580 ${ }^{\circ} \mathrm{C}$ (см. рис. 12). Причину магнитной жесткости мартенситно-стареющих сталей в интервале температур обратного $\alpha \leftrightarrow \gamma$-превращения связывают [44] с перемагничиваем участков $\alpha$-фазы без магнитного взаимодействия между ними, что является результатом большого содержания в стали остаточного аустенита. 
При температурах старения выше $580{ }^{\circ} \mathrm{C}$ эффект стабилизации аустенита уменьшается, что приводит к повышению $M_{\mathrm{S}}$ и снижению $H_{\mathrm{c}}$ (см. рис. 12).

Высокая прочность мартенситно-стареющих сталей объясняется не только дисперсностью и равномерным распределением частиц второй фазы, но и их собственной высокой прочностью [41]. Старение мартенсита вызывает существенное снижение пластичности и ударной вязкости. Однако эти характеристики на стадии максимального упрочнения остаются еще достаточно высокими.

Ферритно-аустенитные стали. Двухфазные ферритно-аустенитные стали со структурой $\delta$-феррит-аустенит обладают более высоким сопротивлением некоторым видам коррозии по сравнению с чисто аустенитными и чисто ферритными нержавеющими сталями и поэтому находят все большее применение. Однако при больших содержаниях $\delta$-феррита эти стали имеют высокую склонность к хрупкому разрушению. Один из возможных путей управления качеством изготовления сталей - использование неразрушающих методов контроля.

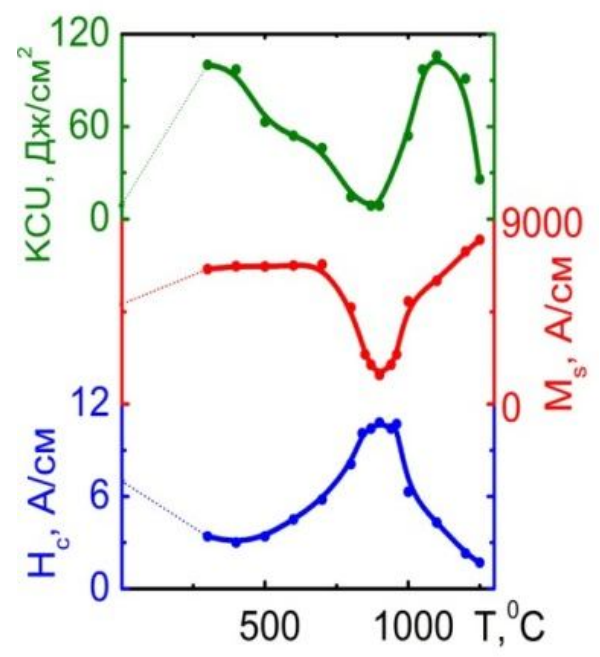

Рис. 13. Зависимость физико-механических свойств ферритно-аустенитной стали от температуры отжига. Предварительная обработка - закалка от $1150{ }^{\circ} \mathrm{C}$

На рис. 13 приведены закономерности изменения физико-механических свойств от температуры отжига сложнолегированной низкоуглеродистой хромоникелевой стали, содержащей $0,05 \% \mathrm{C}, 24 \% \mathrm{Cr}, 7 \% \mathrm{Ni}$ и ряд других элементов. В исходном состоянии (без термической обработки) сталь обладает низким сопротивлением хрупкому разрушению

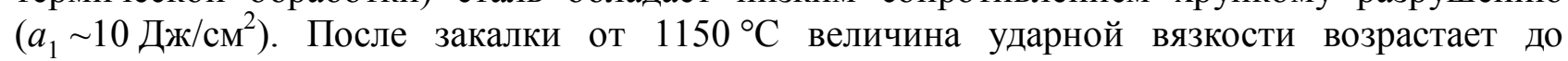
100 Дж/см². Нагрев при температурах 500-700 ${ }^{\circ} \mathrm{C}$ приводит к снижению ударной вязкости примерно в 2 раза. Особенно сильный эффект охрупчивания наблюдается после отжига в диапазоне температур $800-900{ }^{\circ} \mathrm{C}$. Отжиг при $1250{ }^{\circ} \mathrm{C}$ также приводит к значительному падению ударной вязкости. Разрушение во всех случаях происходит по телу зерна.

Таким образом, существует несколько температурных интервалов повышенной склонности к хрупкому разрушению. Охрупчивание при $500-600{ }^{\circ} \mathrm{C}$ сопровождается ростом твердости. Такое изменение свойств указывает на протекание процессов распада легированного феррита с выделением интерметаллидных фаз высокой степени дисперсности [45]. Не исключено, что охрупчивание стали в этом интервале температур частично вызвано процессами, приводящими к "хрупкости $475^{\circ} \mathrm{C} "$ [46].

После выдержки при $900{ }^{\circ} \mathrm{C}$ наблюдается рост твердости. Можно отметить отсутствие корреляции между твердостью и ударной вязкостью. Так, при температуре $800{ }^{\circ} \mathrm{C}$ снижение ударной вязкости не сопровождается ощутимыми изменениями твердости, в то время как при $900{ }^{\circ} \mathrm{C}$ минимальному значению ударной вязкости соответствуют экстремальные значе-

Gorkunov E. S. / Magnetic structural-phase analysis as applied to diagnosing and evaluating the lifetime of products and structural components. Part 1 
ния твердости. Исследования нескольких промышленных плавок этой же стали показали, что охрупчивание в области температур $800-900{ }^{\circ} \mathrm{C}$ может вообще не сопровождаться приростом твердости.

Изучение микроструктуры образцов в литом состоянии, а также после отжига при температурах 800 и $900{ }^{\circ} \mathrm{C}$ [47] показало, что во всех указанных случаях наблюдается образование $\sigma$-фазы, которая выделяется в ферритной составляющей преимущественно в приграничных областях с $\gamma$-фазой. Образование богатой хромом $\sigma$-фазы [46] приводит к изменению состава окружающего ее феррита, который в соответствии с диаграммой состояния превращается в аустенит. Образование вторичного аустенита ( $\gamma^{\prime}$-фазы), как правило, не сопровождается падением ударной вязкости, а в некоторых случаях даже может приводить к снижению критической температуры хрупкости [48]. Основной причиной охрупчивания стали в интервале 800-900 ${ }^{\circ} \mathrm{C}$ является образование $\sigma$-фазы. Литературные данные [49] подтверждают, что появление в двухфазной стали близкого состава $\sigma$-фазы (3-5\%) приводит к снижению ударной вязкости на порядок.

Изучение зависимости магнитных свойств от температуры нагрева показало, что намагниченность насыщения не чувствительна к процессам, протекающим при нагреве до $700{ }^{\circ} \mathrm{C}$ (см. рис. 13), что связано, по-видимому, с небольшим количеством выделяющихся при этих температурах фаз. Повышение температуры приводит к сильному снижению намагниченности насыщения, которая достигает минимального значения при температуре $900{ }^{\circ} \mathrm{C}$. Уменьшение намагниченности насыщения обусловлено распадом $\delta$-феррита на неферромагнитные $\sigma$-фазу и вторичный аустенит, а глубина образовавшегося минимума характеризует их суммарное количество. С повышением температуры величина $M_{\mathrm{S}}$ возрастает, что связано с увеличением количества ферритной фазы.

При температурах выше $1200{ }^{\circ} \mathrm{C}$ структура стали становится полностью однофазной (ферритной). При этом резко возрастает размер ферритного зерна. В этом же интервале температур происходит некоторое повышение твердости стали, которое свидетельствует об обогащении твердого раствора легирующими элементами (в том числе примесями внедрения углеродом, азотом) в результате растворения при этих температурах избыточных карбидных и нитридных фаз. Вероятно, увеличение размеров ферритного зерна, повышение легированности твердого раствора и обогащение границ охрупчивающими элементами - основные причины хрупкости феррита при $T>1200{ }^{\circ} \mathrm{C}$.

Коэрцитивная сила до температур $500{ }^{\circ} \mathrm{C}$ практически не изменяется, хотя для 450 $500{ }^{\circ} \mathrm{C}$ характерно образование интерметаллидов. При дальнейшем увеличении температур происходит рост коэрцитивной силы, вызванный появлением $\sigma$-фазы и вторичного аустенита. При нагреве выше $900{ }^{\circ} \mathrm{C}$ величина коэрцитивной силы достигает максимального значения. Поскольку при этой температуре в стали содержится большое количество остаточного аустенита [47], можно предположить, что участки ферромагнитной фазы ( $\delta$-феррит) в значительной степени обособлены и перемагничиваются, не взаимодействуя друг с другом. В этом случае величина коэрцитивной силы будет зависеть от размеров участков $\delta$-феррита в аустенитной матрице, а также от наличия в $\delta$-феррите $\sigma$-фазы определенной степени дисперсно-

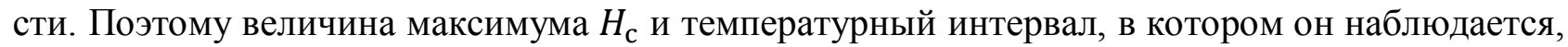
в соответствии с "теорией включений" [2], будут определяться не только количеством $\delta$ феррита, но и объемом и степенью дисперсности $\sigma$-фазы в нем.

На промышленных плавках стали было обнаружено, что максимум коэрцитивной силы не всегда соответствовал минимуму намагниченности насыщения. Однако во всех случаях максимум $H_{\text {c }}$ совпадал с минимумом на кривой ударной вязкости, тогда как минимум $M_{\mathrm{S}}$ мог соответствовать либо минимуму ударной вязкости $\left(900^{\circ} \mathrm{C}\right)$, либо ее максимуму, который в случае промышленных плавок приходился на $T=1000{ }^{\circ} \mathrm{C}$.

Хрупкости, обусловленной ростом зерна и легированности твердого раствора (выше $\left.1200{ }^{\circ} \mathrm{C}\right)$, соответствует значение коэрцитивной силы, более чем в 2 раза меньшее, чем $H_{\mathrm{c}}$ в исходном состоянии (закалка от $1150^{\circ} \mathrm{C}$ ). Повышенная хрупкость стали в литом состоянии, 
по-видимому, также обусловлена главным образом присутствием $\sigma$-фазы, о чем свидетельствуют результаты микроструктурных исследований [47] и повышенное значение коэрцитивной силы.

\section{7 Оценка износостойкости металла}

Износостойкость сталей с мартенситной основой в сильной степени зависит от содержания углерода, находящегося в $\alpha$-твердом растворе. Отпуск, сопровождающийся выделением углерода из мартенсита, приводит к значительному снижению сопротивления закаленных сталей абразивному и адгезионному видам изнашивания [50-52]. Известно [20], что содержание углерода в мартенсите влияет на величины коэрцитивной силы и электросопротивления закаленных сталей. Это дает основание предположить, что износостойкость стальных изделий может быть определенным образом связана с их магнитными или электромагнитными характеристиками. Установление корреляционных связей позволило использовать рассматриваемые магнитные характеристики для аттестации уровня износостойкости стальных поверхностей.

Актуальной производственной задачей является контроль износостойкости рабочих поверхностей трения крупногабаритных объемоупрочненных изделий, а также поверхностных слоев, упрочненных химико-термической обработкой или методами поверхностной закалки (индукционная закалка, лазерная, электронно-лучевая или световая обработка и др.). Для решения этой задачи можно использовать магнитные или электромагнитные методы.

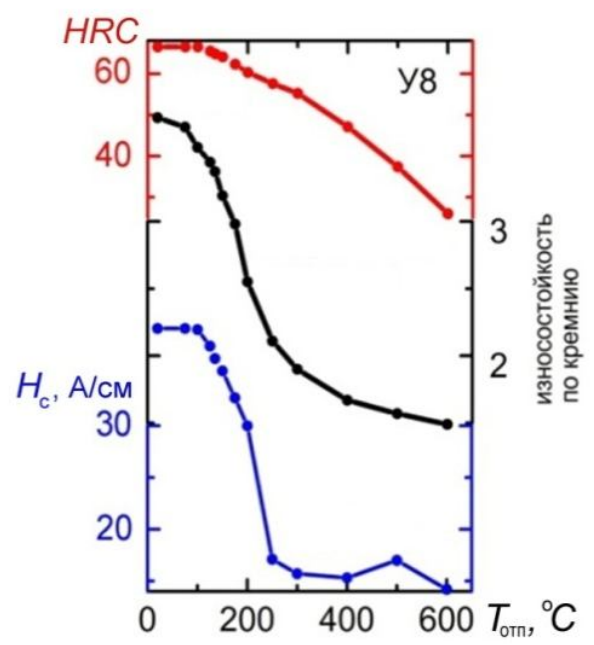

Рис. 14. Влияние температуры отпуска на коэрцитивную силу $H_{c}$, твердость и абразивную износостойкость при испытаниях по кремню закаленной стали 88

Из рис. 14 следует, что низкотемпературный (до $250^{\circ} \mathrm{C}$ ) отпуск приводит к резкому снижению износостойкости и коэрцитивной силы закаленных сталей. Происходящее при этом уменьшение твердости относительно невелико, поскольку разупрочнение за счет снижения уровня тетрагональности мартенсита частично компенсируется упрочнением низкоотпущенного мартенсита дисперсными карбидными частицами.

Как правило, износостойкость закаленных сталей после отпуска при $250{ }^{\circ} \mathrm{C}$ уменьшается в 1,5-1,8 раза при испытании по корунду и в 2,5-3,6 раза - по кремню по сравнению с неотпущенным состоянием. Столь сильная зависимость абразивной износостойкости закаленных сталей от температуры отпуска является следствием снижения содержания углерода в мартенсите при отпуске, которое приводит не только к уменьшению исходной твердости, но и к значительному снижению способности сталей к деформационному упрочнению при изнашивании. Следовательно, присутствие повышенного количества углерода в решетке неотпущенного мартенсита оказывает более интенсивное влияние на деформационное 
упрочнение и износостойкость мартенситной структуры при изнашивании, нежели присутствие в мартенситных кристаллах дисперсных карбидных частиц, выделившихся при низком отпуске. Это связано с развитием в тетрагональном мартенсите под действием трения процессов деформационного динамического старения, приводящего к эффективному закреплению атомами углерода многочисленных дислокаций, возникающих при трении [50-53].

Наблюдаемое в интервале температур отпуска 100-250 ${ }^{\circ} \mathrm{C}$ сильное уменьшение коэр-

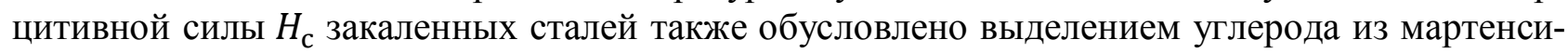
та, которое сопровождается снижением тетрагональности решетки и уменьшением внутренних микронапряжений.

Закономерности изменения коэрцитивной силы и твердости сталей при увеличении температуры отпуска до $400{ }^{\circ} \mathrm{C}$ позволяют заключить, что $H_{\mathrm{c}}$ в значительно большей степени коррелирует с изменением абразивной износостойкости, чем с твердостью. В интервале $T_{\text {отп }}=100-250{ }^{\circ} \mathrm{C}$, когда из тетрагонального мартенсита выделяются атомы углерода, имеет место наиболее существенное и относительно одинаковое по своему характеру изменение абразивной износостойкости и коэрцитивной силы. Наблюдаемое подобие зависимостей и коэрцитивной силы и износостойкости закаленных сталей от содержания углерода в мартенсите, а также высокая чувствительность коэрцитивной силы к присутствию углерода в $\alpha-$ твердом растворе служат физической основой для разработки магнитного метода оценки износостойкости закаленных и низкоотпущенных сталей.

Рассмотренные (см. рис. 14) данные о влиянии температуры отпуска на абразивную износостойкость закаленных различными способами сталей свидетельствуют о том, что за счет оптимизации режима низкого отпуска можно в довольно широких пределах изменять износостойкость сталей. В этой связи возможность магнитного и электромагнитного контроля износостойкости закаленных и низкоотпущенных стальных изделий приобретает особую значимость.

2.8 Контроль структуры, физико-механических свойств и толщины слоев, поверхностно упрочненных различными методами (закалка ТВЧ, химико-термическая обработка, упрочнение концентрированными потоками энергии, виброупрочнение, обезуглероживание в стали и отбел в чугуне)

Контроль качества поверхностного упрочнения [2, 3, 54-71]. В основе неразрушающего контроля глубины и прочностных характеристик упрочненного слоя лежит различие в физических свойствах сердцевины изделия и самого слоя. Чем больше это различие, тем более достоверным и надежным будет метод контроля.

При поверхностном упрочнении существенно увеличивается различие электрических и магнитных свойств упрочненного слоя и сердцевины изделия. Например, при закалке с помощью ТВЧ коэрцитивная сила закаленного слоя в 2-4 раза больше коэрцитивной силы сердцевины. Это объясняется тем, что структура сердцевины “феррит+перлит” является мягкой в магнитном отношении $\left(H_{\mathrm{c}}=8-12 \mathrm{~A} / \mathrm{cm}\right)$. Закаленный слой имеет структуру мелкоигольчатого мартенсита с высокой коэрцитивной силой $\left(H_{\mathrm{c}}=25-28 \mathrm{~A} / \mathrm{cm}\right)$. Высокое значе-

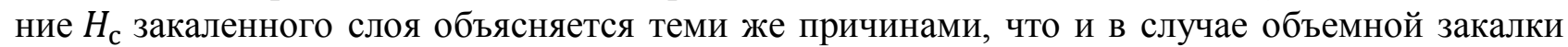
стали.

Для цементированного слоя и сердцевины установлено, что наибольшее их различие (до 10 раз) достигается после закалки. Закономерности изменения магнитных и электрических свойств цементированного слоя и сердцевины изделия при вариации температуры закалки близки к закономерностям, характерным для заэвтектоидных углеродистых и низкоуглеродистых слаболегированных сталей соответственно (см. рис. 10).

Поверхностное упрочнение путем пластической деформации также приводит к изменению магнитных и электрических свойств поверхностного слоя за счет роста количества дефектов кристаллического строения.

Gorkunov E. S. / Magnetic structural-phase analysis as applied to diagnosing and evaluating the lifetime of products and structural components. Part 1 
Упрочненные слои могут иметь разные толщины, например, для цементированных слоев десятые доли миллиметров, а для поверхностно закаленных валков холодной прокатки 10-15 мм. Для обеспечения необходимой глубины проникновения магнитного потока в контролируемый поверхностный слой выбирают необходимое сечение полюсов [71] приставного магнитного устройства (см. рис. 15).

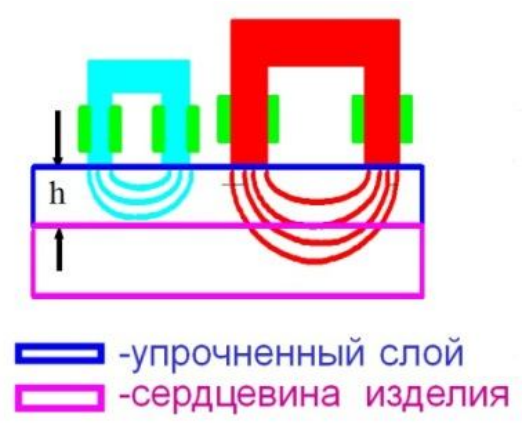

Рис. 15. Схематическое изображение проникновения магнитного потока в поверхностно упрочненное изделие при использовании приставных электромагнитов разного сечения

Использование коэрцитиметров для контроля качества поверхностного упрочнения изделий машиностроения. Коэрцитиметры с П-образными приставными электромагнитами позволяют осуществить контроль деталей, имеющих упрочненные слои примерно от 0,4 до нескольких десятков миллиметров. В качестве примера контроля больших толщин упрочненных слоев могут служить валки холодной прокатки, выпускаемые Уральским заводом тяжелого машиностроения. Глубина активного закаленного слоя должна быть не менее 3\% от радиуса валка, который менялся от 65 до 450 мм. Максимальная глубина закаленного слоя достигала 10-15 мм, поэтому геометрические размеры электромагнита подбирали такими, чтобы можно было определять среднюю коэрцитивную силу на глубине 15-20 мм. Связь показаний коэрцитиметра с глубиной активного закаленного слоя валка линейная (рис. 16).

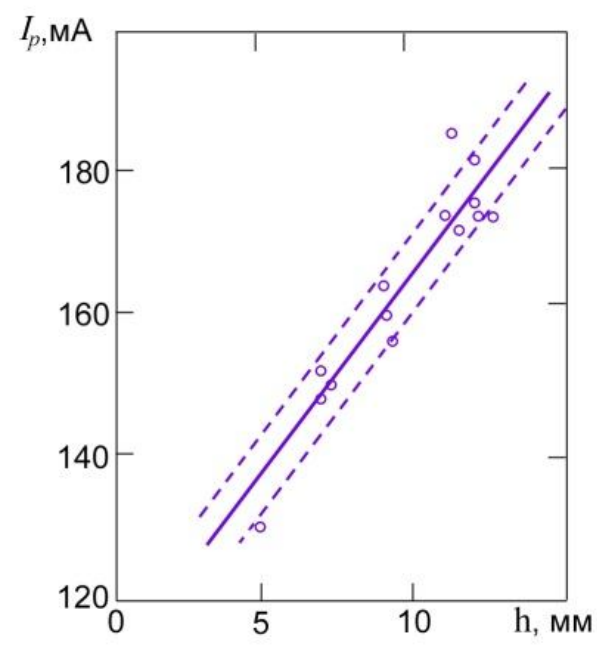

Рис. 16. Зависимость показаний коэрцитиметра от толщины упрочненного слоя валков холодной прокатки

Исследования с одно- и двухслойными изделиями [60] позволили получить в относительных единицах обобщенную кривую зависимости показаний коэрцитиметров от сечения полюсов электромагнита, на которой выделены четыре участка (рис. 17). 


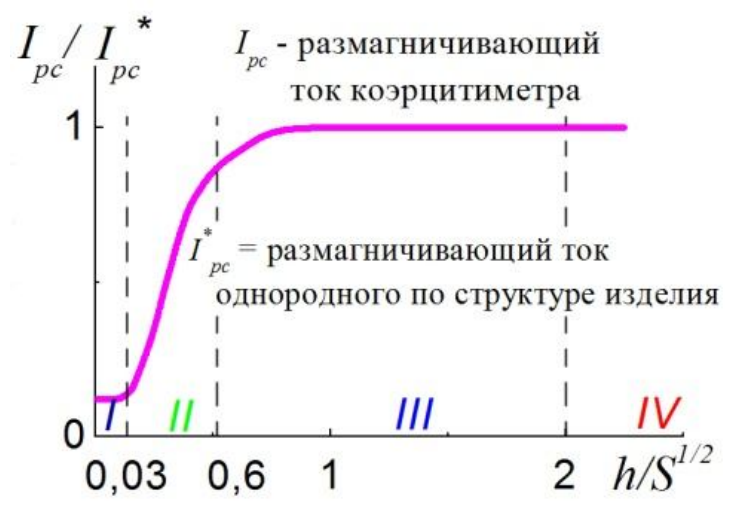

Рис. 17. Обобщенная кривая зависимости показаний коэрцитиметров в относительных единицах

$I$ участок от 0 до $h_{\mathrm{H}} \cong 0,03 \sqrt{S_{\ni}}$. Показания коэрцитиметра практически постоянны и зависят главным образом от коэрцитивной силы незакаленной сердцевины. Здесь $h_{\mathrm{H}}-$ начальная величина поверхностного слоя, начиная с которой показания коэрцитиметра заметно увеличиваются с ростом толщины упрочненного слоя.

$I I$ участок от $h_{\mathrm{H}}$ до $h_{\text {к }} \cong 0,6 \sqrt{S_{\ni}}$. Показания коэрцитиметра зависят от коэрцитивной силы и толщины закаленного слоя и от коэрцитивной силы сердцевины $\left(h_{\mathrm{\kappa}}-\right.$ предельная контролируемая толщина закаленного слоя).

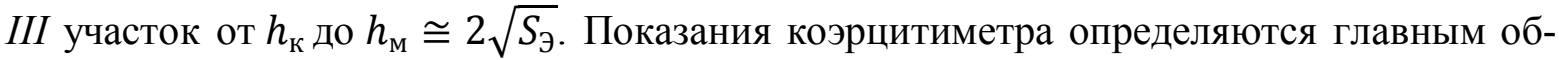
разом коэрцитивной силой закаленного слоя и слабо зависят от изменения его толщины и свойств сердцевины.

$I V$ участок $h \geq h_{\mathrm{M}}$. Показания коэрцитиметра зависят только от коэрцитивной силы закаленного слоя и практически не зависят от магнитных свойств сердцевины изделия.

Обобщенная кривая позволяет сделать вывод, что основной характеристикой электромагнита при контроле массивных изделий является площадь полюсов, и если известна толщина закаленного слоя, то можно выбрать параметры электромагнита с необходимой глубиной проникновения магнитного потока в изделие.

Параметры электромагнита, соответствующие участку $I$ кривой, следует выбирать, когда контролю подвергают мягкую сердцевину изделия и пренебрегают свойствами тонкого поверхностного слоя, например при обезуглероживании. Условия, соответствующие участку $I I$, используются при контроле поверхностного закаленного слоя, когда его толщина изменя-

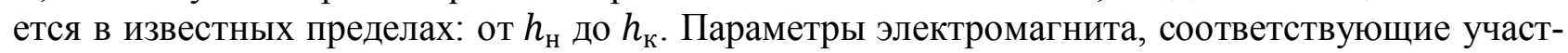
ку $I V$, используют для контроля свойств однородных массивных изделий, например физикомеханических свойств упрочненного слоя, так как в этом случае на измерения не влияет их толщина.

В существующих методиках контроля глубины и твердости упрочненного слоя, как правило, измеряют один параметр, например размагничивающий ток коэрцитиметра. Однако по одному измеренному магнитному параметру трудно судить о толщине закаленного слоя и его твердости, особенно в случаях, когда исходная структура изделий перед закалкой меняется. Для повышения достоверности контроля необходимо увеличить число измеряемых параметров, учитывающих влияние изменений всех технологических процессов. В случае закалки с помощью ТВЧ задачу контроля можно решить следующим образом. Исходя из обобщенной кривой, можно подобрать электромагниты, которые будут чувствительны только к структурному состоянию закаленного слоя или отражать усредненные магнитные свойства закаленного слоя и сердцевины изделия. Рис. 18 иллюстрирует возможности контроля толщины закаленного слоя штоков бурового оборудования с помощью приставных электро- 
магнитов, имеющих различное сечение полюсных наконечников. Приставной электромагнит с $S_{\ni}=40$ мм $^{2}$ (рис. $18 a$ ) может быть использован для определения толщин закаленного слоя

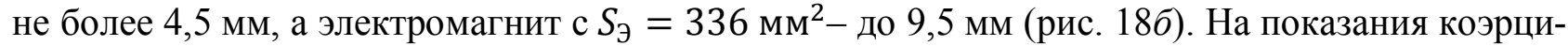
тиметра кроме толщины закаленного слоя оказывают влияние магнитная жесткость самого слоя и исходная структура изделия до закалки.

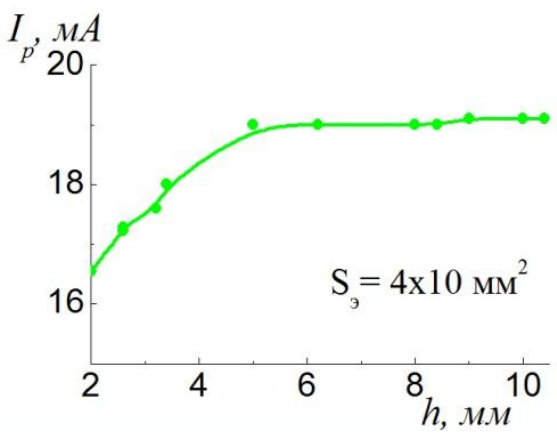

$a$

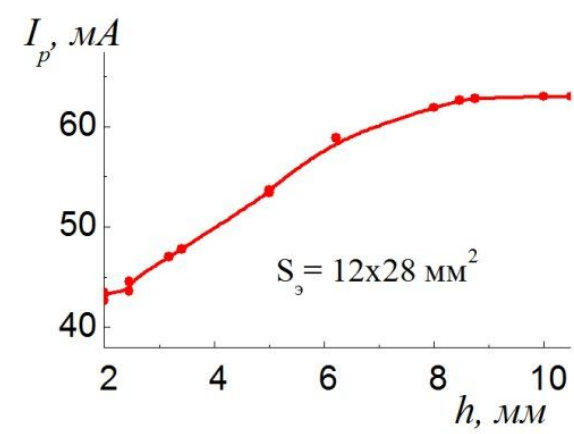

$\sigma$

Рис. 18. Зависимость показаний коэрцитиметра от толщины закаленного слоя штоков бурового оборудования: $a$ - сечение электромагнита $40 \mathrm{Mм}^{2}, \sigma-336 \mathrm{mм}^{2}$

Для учета влияния исходной структуры металла на результаты контроля обычно рекомендуется проверять изделия в несколько этапов. Вначале контролируют исходную структуру изделия перед закалкой ТВЧ и по результатам измерений подразделяют изделия на группы с близкими магнитными свойствами исходной структуры, а затем проводят термообработку и последующий неразрушающий контроль по группам. Если удастся оценить магнитные свойства исходной структуры (измерить величину размагничивающего тока коэрцитиметра), то ее влияние на результаты контроля учитываются графически или аналитически:

$$
h=\mathrm{A} \frac{I_{\mathrm{ph}}}{I_{\mathrm{pu}}}-\mathrm{C}
$$

где $I_{\mathrm{ph}}$ - размагничивающий ток коэрцитиметра при контроле поверхностно упрочненного изделия; $I_{\mathrm{pu}}$ - размагничивающий ток коэрцитиметра при контроле исходной структуры на термически необработанном участке изделия. Коэффициенты А и С зависят от выбора преобразователя, формы полюсных наконечников, геометрии изделия и определяются эмпирически для каждого отдельного случая.

Контроль прочностных свойств упрочненного слоя можно осуществить при малой глубине проникновения магнитного потока в изделие. Это достигается использованием приставных электромагнитов, удовлетворяющих условию $h>0,6 \sqrt{S_{\ni}}$. Таким образом, при использовании двух и более приставных электромагнитов, имеющих различное сечение и при наличии трех измеренных параметров, возможно определение твердости поверхностно упрочненных изделий:

$$
H R C=a_{0}+a_{1} I_{\mathrm{pm}}-a_{2} \frac{I_{\mathrm{ph}}}{I_{\mathrm{pu}}}+a_{3} I_{\mathrm{pu}},
$$

где $I_{\mathrm{pм}}$ - размагничивающий ток коэрцитиметра, получаемый при контроле закаленной части изделия приставным электромагнитом с малым сечением полюса. При контроле штоков бурового оборудования коэффициенты $a=42,5 ; a_{1}=1,2 ; a_{2}=0,10$ и $a_{3}=0,16$ просчитаны на основании измерений магнитных и механических свойств изделий, прошедших поверхностную закалку и последующий отпуск при $150-180{ }^{\circ} \mathrm{C}$. Аналогичный способ использован для контроля поверхностно закаленных шеек коленчатых валов [66] при помощи коэрцитиметра с 
двумя приставными электромагнитами, имеющими различное сечение полюсных наконечников, что позволило с большей степенью достоверности определять твердость и глубину закаленного слоя.

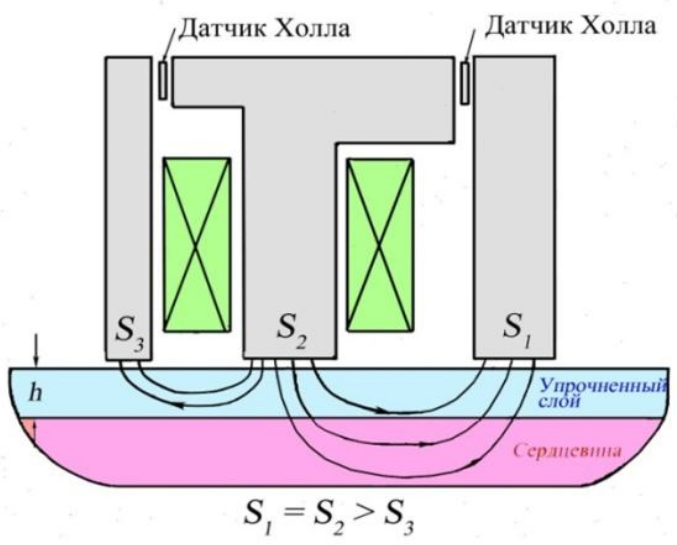

Рис. 19. Приставной Ш-образный электромагнит с различным сечением полюсов

Недостатком в использовании П-образных преобразователей является невозможность раздельного определения глубины и твердости упрочненного слоя одним электромагнитом, поэтому предложено использовать комбинированный Ш-образный магнит, у которого полюса имеют различное сечение (рис. 19). Использование подобных электромагнитов позволяет в процессе одного измерения получить информацию о толщине упрочненного слоя и его твердости [2, 3, 67-69].

Таким образом, с помощью магнитных методов возможны неразрушающее определение структуры, фазового состава и прочностных характеристик термически обработанных стальных и чугунных изделий машиностроения, а также оценка глубины и твердости поверхностно упрочненных деталей.

Все описанные методы позволяют определять глубину и твердость поверхностных слоев, в то время как свойства неупрочненной сердцевины изделия иногда имеют важное значение для качества упрочненных изделий, особенно когда перед поверхностным упрочнением изделие подвергают объемной термической закалке и отпуску. Проблему одновременного определения свойств как поверхностно упрочненного слоя, так и сердцевины изделия можно в некоторых случаях решить путем использования особенностей перемагничивания двухслойного ферромагнетика [2, 3, 67-70].

Петля гистерезиса двухслойного ферромагнетика имеет искаженный вид. На рис. $20 a$ показаны петли гистерезиса двух однородных материалов (кривые 1 и 2) и двухслойного образца (кривая 3), состоящего из этих материалов. Поскольку образцы представляли собой тороиды, имеющие одинаковые размеры, и перемагничивание происходило вдоль плоскости раздела слоев, кривая 3 может быть получена путем аддитивного сложения двух первых с учетом сечения каждого из слоев:

$$
B(H)=\frac{S_{1}}{S} B_{1}(H)+\frac{S_{2}}{S} B_{2}(H),
$$

где $B_{1}$ и $B_{2}$ - индукция первого и второго слоев; $B$ - средняя по сечению индукция двухслойного образца; $S$ - поперечное сечение двухслойного образца; $S_{1}$ и $S_{2}$ - поперечное сечение первого и второго слоев. Петли гистерезиса, рассчитанные по формуле (4) и определенные экспериментально, практически совпадали. Перегибы петли гистерезиса (рис. 20, кривая 3), свидетельствуя о наличии второго слоя, отличного от основной массы материала, не характеризуют количественно ни его толщину, ни его свойства. 

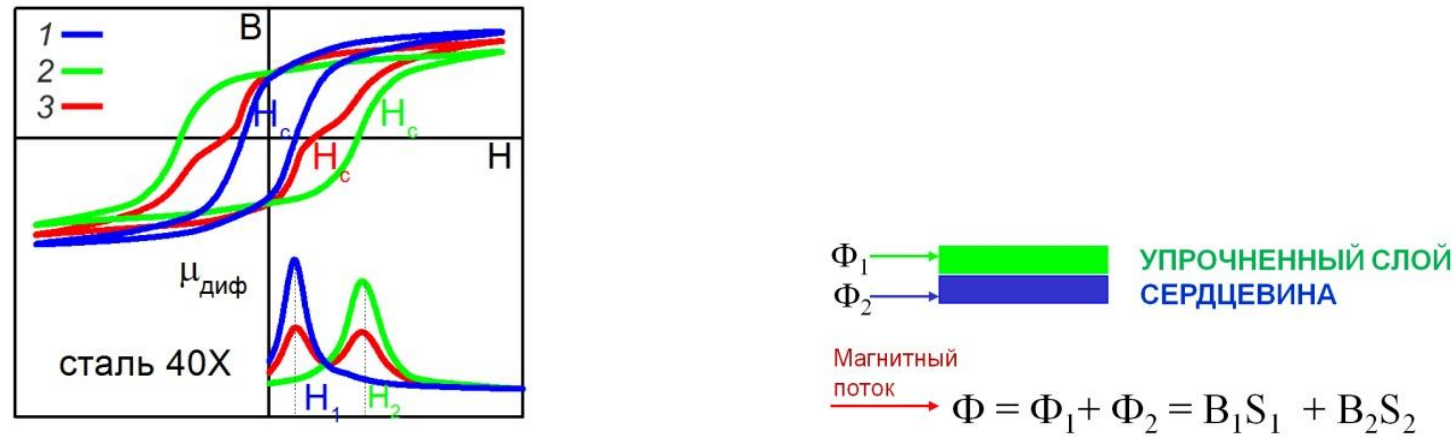

Рис. 20. Петли магнитного гистерезиса и дифференциальные проницаемости однородных и двухслойных изделий

Более информативна зависимость дифференциальной магнитной проницаемости $\mu_{\text {диф }}$ от напряженности перемагничивающего поля $H$. Наиболее простым способом получения зависимостей $\mu_{\text {диф }}(H)$ и определения полей $H_{1}$ и $H_{2}$, при которых происходит образование перегибов, является измерение ЭДС катушки, охватывающей образец при его перемагничивании линейно изменяющимся током. При этом

$$
e=-\omega \frac{d \Phi}{d t}=-\omega \frac{d \Phi}{d H} \frac{d H}{d t}=-\omega \frac{d H}{d t}\left(\frac{d \Phi_{1}}{d H}+\frac{d \Phi_{2}}{d H}\right) \simeq-\omega \frac{d H}{d t}\left(S_{1} \mu_{\text {диф1 }}+S_{2} \mu_{\text {диф2 }}\right),
$$

где $\Phi, \Phi_{1}, \Phi_{2}$ - магнитные потоки в двухслойном образце и в каждом из слоев соответственно. Поскольку $\frac{d H}{d t}=$ const, то

$$
e=k\left(S_{1} \mu_{\text {диф1 }}+S_{2} \mu_{\text {диф2 }}\right) \text {. }
$$

Если слои однородны по своему сечению, то

$$
h \mu_{\text {диф }}=h_{1} \mu_{\text {диф1 }}+h_{2} \mu_{\text {диф } 2},
$$

где $h_{1}$ и $h_{2}$ - относительные толщины каждого из слоев. Как правило, проницаемость магнитожесткого упрочненного слоя мала в поле, при котором проницаемость магнитомягкого слоя достигает своего максимума, и наоборот, т. е. дифференциальная магнитная проницаемость в поле $H_{\mu_{\text {диф1 }}}$ будет определяться произведением $h_{1} \mu_{\text {диф1 }}$, а в поле $H_{\mu_{\text {диф2 }}}-h_{2} \mu_{\text {диф2 }}$. Известно, что поле максимальной дифференциальной проницаемости образца практически совпадает со значением его коэрцитивной силы. Таким образом, находя значения $H_{1}$ и $H_{2}$ по местоположению максимумов $e$ на кривой $e(H)$ (см. рис. 20) для двухслойного образца, можно получить информацию о величине коэрцитивной силы и физическо-механических свойствах того или другого слоя, а по известным закономерностям $e \approx \mu_{\text {дифтах }}$ определить толщину закаленного слоя.

Дифференциальная магнитная проницаемость, определенная при линейно измеряющемся во времени поле путем измерения ЭДС измерительной обмотки, для серии модельных образцов с различными толщинами закаленного слоя и сердцевины представлена на рис. $21 a$.

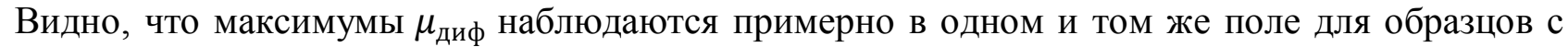
различным соотношением слоев и с одинаковыми от образца к образцу свойствами этих слоев. На рис. 216 приведены зависимости для однородных (кривые 1 и 2) и двухслойных (кривая 3) образцов стали 45. Слои последних изготовлены из тех же материалов, что и однородные образцы. Из рисунка следует, что поля максимальной дифференциальной проницаемо- 
сти однородных материалов соответствуют аналогичным полям двухслойных образцов, изготовленных из тех же материалов.

Таким образом, поле максимальной дифференциальной магнитной проницаемости характеризует структурное состояние каждой из компонент, а высоты пиков относительное содержание каждой из компонент (в нашем случае толщины поверхностно упрочненного слоя и сердцевины изделия).
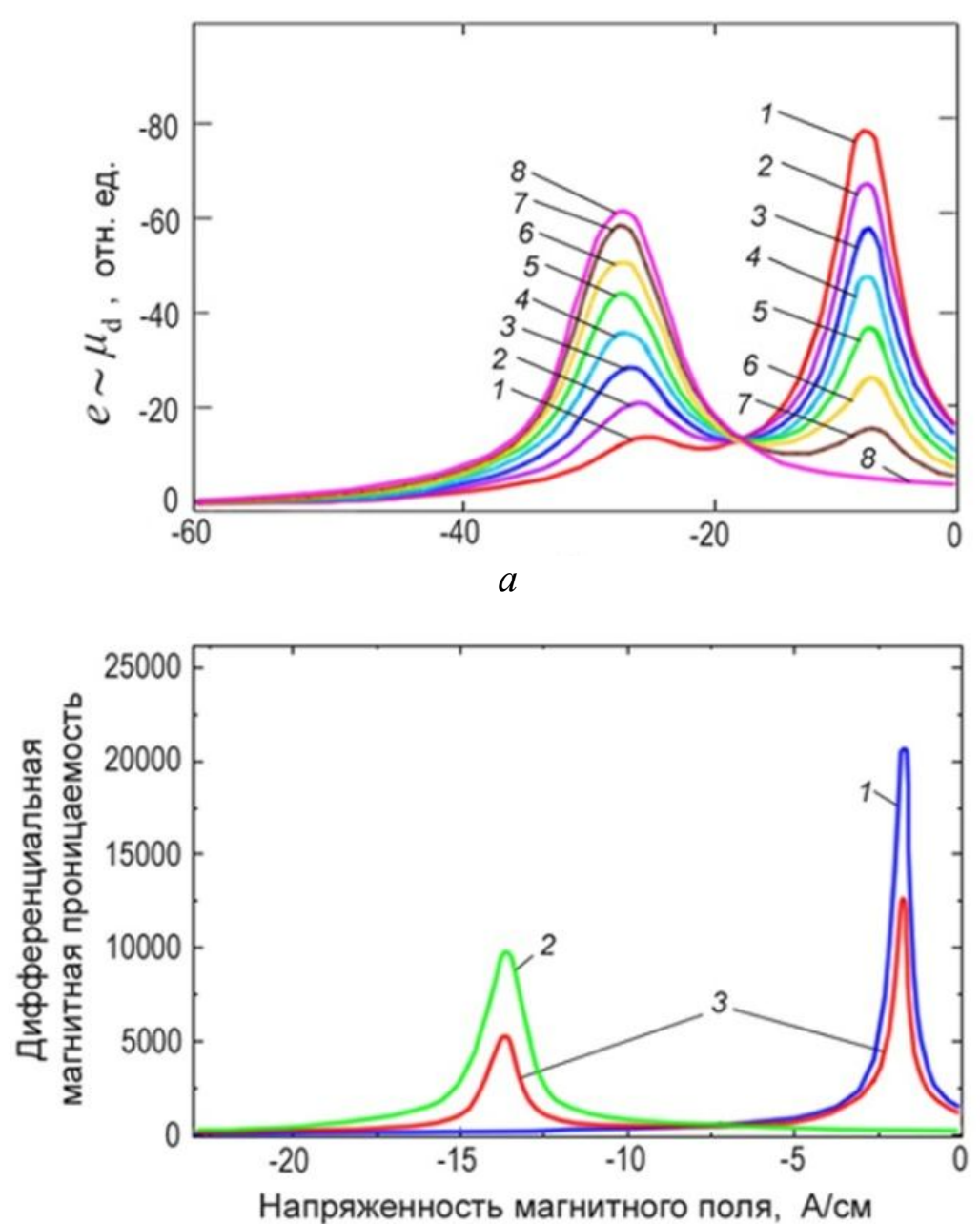

6

Рис. 21. Полевые зависимости дифференциальной магнитной проницаемости для однородных и двухслойных тороидов:

$a-$ с различным содержанием магнитомягкого и магнитожесткого слоев:

1 - толщина магнитомягкого слоя 7 мм, магнитожесткого 1 мм, $2-6$ и 2 мм, 3 - 5 и 3 мм, 4 - 4 и 4 мм, 5 - 3 и 5 мм, $6-2$ и 6 мм, $7-1$ и 7 мм, $8-0$ и 8 мм;

$\sigma$ - с различными по свойствам упрочненными слоями:

1 - однородный образец из стали 45 в исходном состоянии;

2 - однородный образец из стали 45, закаленный в масло;

3 - двухслойный образец, составленный из материалов 1 и 2

Наглядно изменение структуры и дифференциальной магнитной проницаемости можно проследить на примере рис. 22. Поверхностное упрочнение лазером приводит к образованию мартенситных структур (структура 1) с повышенной твердостью поверхностного слоя и

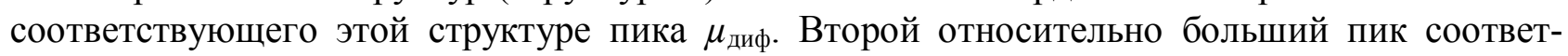


ствует сердцевине изделия (структура 3). Послойное сошлифовывание поверхностного слоя

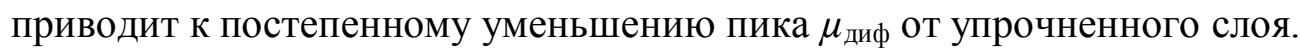

1 - поверхностный слой; 2 - переходная зона; 3 - сердцевина образца
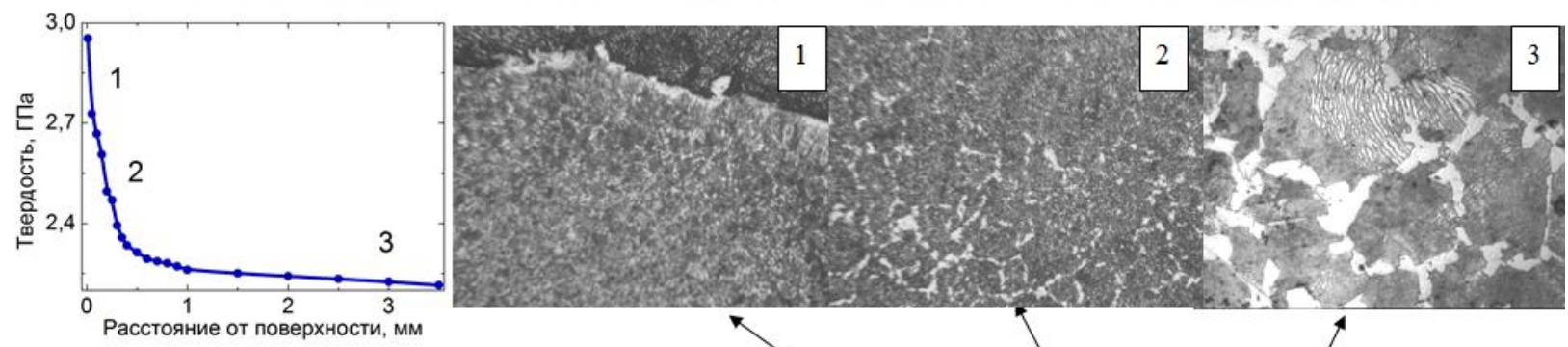

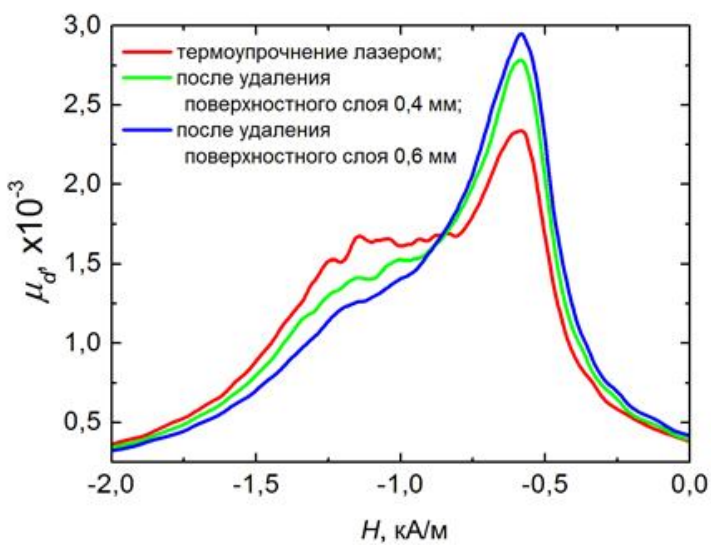

$a$

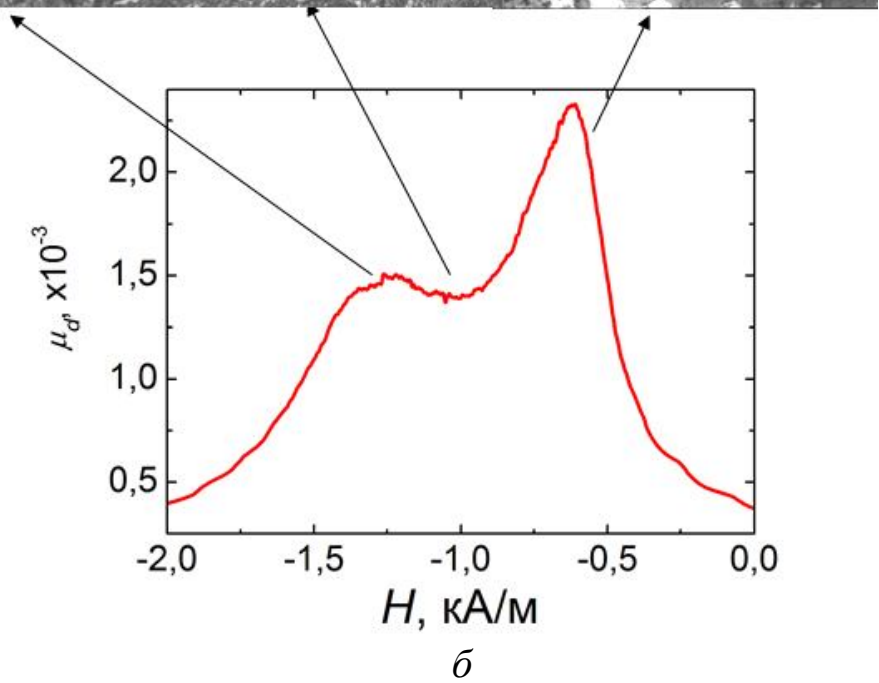

$\sigma$

Рис. 22. Микроструктура, магнитные характеристики и твердость образца стали 45, термоупрочненного лазером

Аналогичные закономерности изменения максимальной дифференциальной магнитной проницаемости были получены для образцов, вырезанных из сварных соединений, которые имеют различающиеся структуры основного металла и околошовной зоны (рис. 23).

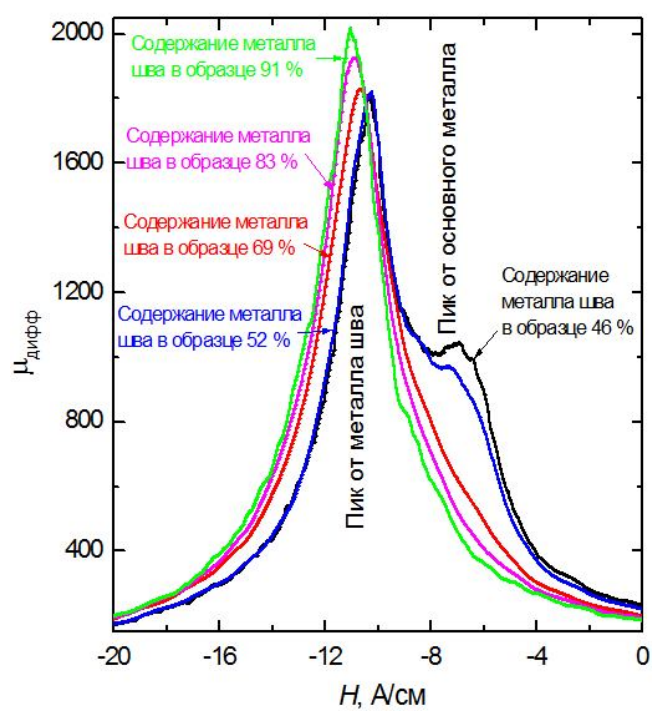

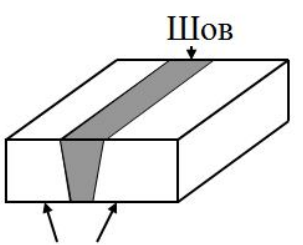

Основной металл

Взаимосвязь коэрцитивнойсилы и твердости трубной стали класса прочности X70

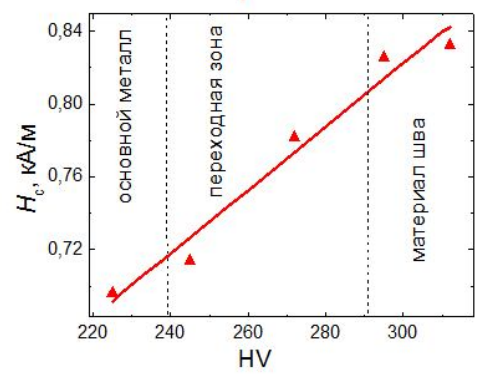

Рис. 23. Полевые зависимости дифференциальной магнитной проницаемости образцов сварных соединений при различном соотношении в них основного металла и металла шва 
В зависимости от того, какой объем анализируется в зоне контроля, зависят высоты пиков для обеих составляющих. Из рис. 24 следует, что по мере сокращения объема металла околошовной зоны высота соответствующего пика уменьшается.

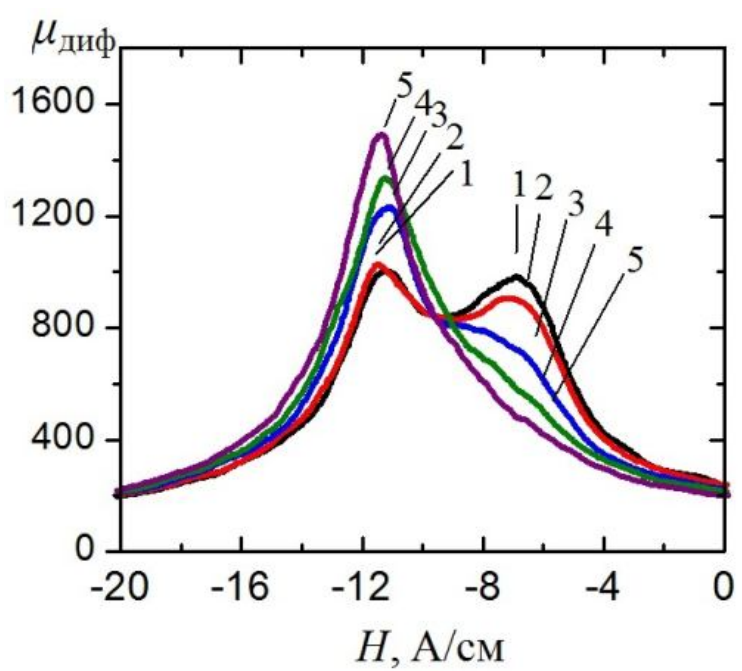

Рис. 24. Полевые зависимости дифференциальной магнитной проницаемости для различных вариантов изменения ширины всего образца со сварным соединением из стали Х70:

$$
1 \text { - ширина образца } 45 \text { мм; } 2 \text { - 40; } 3 \text { - 30; 4-25; } 5 \text { - } 20
$$

Таким образом, на основе зависимостей $\mu_{\text {диф }}(H)$ как на стадии изготовления, так и в процессе эксплуатации контролируемого изделия, по значениям напряженности магнитного поля, в которых локализируются максимумы дифференциальной магнитной проницаемости, можно отслеживать изменения структурного состояния и механических характеристик отдельных зон, имеющих различия магнитных свойств.

\section{Литература}

1. Kryloff M. Balance electro-magnetigue pour l'essal des proprietes des asiers et des fers // Revur Metallurgie. - 1905. - № 2. - P. 425-440.

2. Михеев М. Н., Горкунов Э. С. Магнитные методы структурного анализа и неразрушающего контроля. - М. : Наука, 1993. - 251 с.

3. Щербинин В. Е., Горкунов Э. С. Магнитный контроль качества металлов. Екатеринбург : УрО РАН, 1996. - 264 с.

4. Горкунов Э. С., Ульянов А. И. Магнитные методы и приборы контроля качества изделий порошковой металлургии. - Екатеринбург : УрО РАН, 1996. - 204 с.

5. Yensen T. D., Ziegler N. A. Magnetic properties of iron as affected by carbon, oxygen and grain-size // Trans. Amer. Soc. Met. - 1935. - Vol. 23. - P. 556-557.

6. Sizoo G. J. Über den Zusammenhang zwischen Korngröße und magnetischen Eigenschaften bei reinem Eisen // Ztschr. Phys. - 1928. - Bd. 1. - S. 557-561.

7. Производство низкоуглеродистого железа / Р. Д. Гутнов, Б. Н. Сухотин, И. Я. Сокол и др. - М. : Металлургия, 1973. - С. 7-20.

8. Литвиненко Д. А., Матросов Ю. И. Влияние регулируемой прокатки на свойства сталей // Сталь. - 1974. - № 10. - С. 931-936.

9. Дреге В. Сталь как конструкционный материал. - М. : Металлургия, 1967. - 375 с.

10. К Коган Л. И., Клейнер Л. М., Энтин Р. И. Особенности превращения аустенита в малоуглеродистых легированных сталях // ФММ. - 1976. - Т. 41, вып. 1. - С. 118-123.

11. Одинг М. А. Прочность металлов. - М.-Ленинград: ОНТИ МетП, 1957. - 565 с. 
12. Бернштейн М. Л. Структура деформированных сплавов. - М. : Металлургия, 1977. $-430 \mathrm{c}$.

13. Вистер Г. И., Даль В., Хэнгстэнберг Х. Влияние условий прокатки в особенности температуры ее конца на механические свойства низколегированных и низкоуглеродистых сталей // Черные металлы. - 1962. - № 17. - С. 34-46.

14. Kneller E. Ferromagnetismus. - Berlin, Guttingen, Heidelberg : Springer-Verlag, 1962. $-792 \mathrm{~s}$.

15. Лифшиц Б. Г. Физические свойства металлов и сплавов. - М. : Машгиз, 1959. - 368 с.

16. Mel'gui M. A., Vostrikov A. A., Zborovskii A. A. Magnetic inspection of the mechanical properties of cold-rolled steel sheet // The Soviet journal of nondestructive testing. - 1971. - Vol. 7, № 3. - P. 248-252.

17. Бида Г. В., Горкунов Э. С., Шевнин В. М. Магнитный контроль механических свойств проката. - Екатеринбург : УрО РАН, 2002. - 251 с.

18. Mikheev M. N., Gorkunov E. S. Magnetic method of nondestructive testing of the structure condition and strength characteristics of heat-treated parts (review) // The Soviet Journal of Nondestructive Testing. - 1985. - Vol. 21, № 5. - P. 330-333.

19. Gorkunov E. S. Magnetic structure and phase analysis of ferromagnetic steels and alloys // Russian Journal of Nondestructive Testing. - 1991. -№ 4. - P. 231-259.

20. Морозова В. М., Михеев М. Н. Магнитные и электрические свойства закаленных и отпущенных углеродистых сталей // Тр. ИФМ АН СССР. - 1965. - Вып. 24. - С. 26-35.

21. Михеев М. Н., Жукова П. Н., Томилов Г. С. Магнитные и электрические свойства легированных сталей после различных термических обработок // Тр. ИФМ АН СССР. - 1954. Вып. 15. - С. 90-102.

22. Mikheev M. N., Somova V. M., Gorkunov E. S. Magnetic inspection for quality control of heat treatment of products made of structural steel grades 45 and 50 // The Soviet Journal of Nondestructive Testing. - 1980. - № 7. - P. 495-500.

23. Михеев М. Н., Горкунов Э. С. Магнитные методы контроля закалки и последующего отпуска изделий из низколегированных конструкционных сталей // Тр. ИФМ АН СССР. 1979. - Вып. 37. - С. 3-14.

24. Interrelation of the magnetic and mechanical properties with the structural state of hardened and tempered products / M. N. Mikheev, E. S. Gorkunov, V. M. Somova, A. B. Kut'kin // The Soviet Journal of Nondestructive Testing. - 1982. - Vol. 18, № 9. - P. 725-732.

25. Жукова П. Н., Михеев М. Н. Магнитные свойства хромоникельмолибденовых сталей после различной термической обработки // ЖТФ. - 1948. - Т. 18, вып. 2. - С. 187-196.

26. Magnetic, electrical and mechanical properties of steel 35SGM after hardening and tempering / I. A. Kuznetsov, A. I. Bagrov, L. Kh. Radionova, V. M. Somova // The Soviet journal of nondestructive testing. - 1978. - Vol. 14, № 7. - P. 609-614.

27. Gorkunov E. S., Mikheev M. N., Dunaev F. N. Effects of heat treatment on the magnetic and electrical properties of $18 \mathrm{KhNVA}, 34 \mathrm{KhN} 3 \mathrm{M}$, and U9A steels // The Soviet Journal of Nondestructive Testing. - 1975. - № 3. - P. 368-373.

28. Mikheev M. N., Gorkunov E. S. Magnetic methods of monitoring Quality of heat treatment // Melbourne: Ninth world conference on non-destructive testing. - 1979. - 4A-10.

29. Mikheev M. N., Somova V. M., Gorkunov E. S. Nondestructive magnetic quality-control method for the heat treatment of steels $30 \mathrm{KhN} 2 \mathrm{MFA}$ and $40 \mathrm{Kh} / /$ The Soviet Journal of Nondestructive Testing. -1979 . - no. 10. - P. 863-868,

30. Михеев М. Н, Горкунов Э. С. О возможных причинах различия процессов перемагничивания в слабых и средних магнитных полях термически обработанных конструкционных сталей // ФММ. - 1981. - Т. 51, вып. 4. - С. 749-755.

31. Magnetic inspection of products of steels $7 \mathrm{Kh} 3,9 \mathrm{KhF}, 50 \mathrm{KhNM}, \mathrm{U} 10 \mathrm{~A}$ after low and medium tempering / E. S. Gorkunov, V. N. Kostin, M. V. Tartachnaya, A. G. Glazistov, V. N. Shalaev

// The Soviet Journal of Nondestructive Testing. - 1990. - no. 1. - P. 65-70. 
32. Gorkunov E. S., Gavrilova L. D., Nichipuruk A. P. Magnetic and electromagnetic method for quality control of quenching and tempering and determination of retained austenite in $95 \mathrm{Kh} 18$ steel products // Russian Journal of Nondestructive Testing. - 1995. - no. 12. - P. 897-905.

33. Mikheev M. N., Gorkunov E. S., Dunaev F. N. Nondestructive magnetic inspection of hardened and tempered parts of low-alloy constructional and plain carbon steel. I // The Soviet Journal of Nondestructive Testing. - 1977. - no. 6. - P. 613-617.

34. Mikheev M. N., Gorkunov E. S., Dunaev F. N. Nondestructive magnetic inspection of hardened and tempered parts of low-alloy constructional and plain carbon steel. II // The Soviet Journal of Nondestructive Testing. - 1977. - no. 6. - P. 618-622.

35. Магнитный контроль качества закалки и отпуска деталей шариковых и роликовых подшипников / М. Н. Михеев, Г. С. Томилов, М. Ф. Помухин и др. // Заводская лаборатория. - 1956. - № 5. - C. 549-555.

36. Differential measuring instrument of magnetic characteristics / M. N. Mikheev, E. S. Gorkunov, A. V. Antonova, M. I. Shirobokov, V. V. Nikitin // The Soviet Journal of Nondestructive Testing. - 1982. - no.12. - P. $982-984$.

37. Filippov A. V., Gorkunov E. S., Kuzminykh V. P. The Dimkh-2 magnetic characteristic differential gauge // The Soviet Journal of Nondestructive Testing. - 1990. - no. 4. - P. 280-283.

38. Использование дифференциальных магнитных структуроскопов для контроля качества композитных материалов / Э. С. Горкунов, Г. В. Сурин, А. П. Ничипурук, В. М. Сомова // Механика композитных материалов. - 1992. - № 6. - С. 838-840.

39. Gorkunov E. S., Somova V. M., Buldakova N. B. Resistance of the remanent magnetization state of steel subjected to various heat treatments to the effect of constant demagnetizing fields // The Soviet Journal of Nondestructive Testing. - 1986. - no. 9. - P. 586-594.

40. Gorkunov E. S., Batukhtina I. N. Examination of the kinetics of magnetic properties in tempering structural steel with special reference to active inspection of their quality // The Soviet Journal of Nondestructive Testing. - 1987. - Vol. 23, no. 3. - P. 177-182.

41. Перкас М. Д., Кардонский В. М. Высокопрочные мартенситостареющие стали М. : Металлургия, 1970. - 224 с.

42. Перкас М. Д. Структура и свойства высокопрочных сталей со стареющим мартенситом // Металловедение и термическая обработка металлов. - 1970. - № 7. - С. 12-24.

43. Лившиц Б. Г., Крапошин В. С., Линецкий Я. Л. Физические свойства металлов и сплавов - М. : Металлургия, 1980. -318 с.

44. Магнитные свойства железоникелевых сплавов, легированных алюминием и титаном, после отпуска в интервале температур $\alpha \rightarrow \gamma$-превращения / И. Я. Дехтяр, В. В. Полотнюк, В. Г. Горбач и др. // Металлофизика. - 1984. - Т. 6, № 2. - С. 65-69.

45. Сокол И. Я. Двухфазные стали. - М. : Металлургия, 1974. - 216 с.

46. Гудремон Э. Специальные стали. - М. : Металлургия, 1966. - Т. 1. - 736 с.

47. Examination of the possibilities of magnetic inspection of the susceptibility of a two-phase ferritic-austenitic steel to embrittlement / V. V. Zabilskii, E. S. Gorkunov, N. I. Ugarova, I. M. Murakhovskii // The Soviet Journal of Nondestructive Testing. - 1987. - Vol. 23, no. 3. - P. 177-182.

48. Hoshino A. Influence of austenite on toughness of two phase stainless steels / A. Hoshino, K. Nakao, M. Kanao // Trans. Nat.Res. Inst. Met. - 1980. - Vol. 22, no. 4. - P. 185-194.

49. Precipitation behavior of $\sigma$-phase induplex phase stainless / C. Maehara, M. Koike, N. Fujine, T. Kunitake // Tetsu to hanage. - 1981. - Vol. 67, no. 3. - P. 577-587.

50. Коршунов Л. Г., Макаров А. В., Осинцева А. Л. Исследование износостойкости и структурных превращений при абразивном изнашивании стали У8, упрочненной лазером // Трение и износ. -1988 . - Т. 9, № 1. - С. 52-59.

51. Макаров А. В., Коршунов Л. Г., Осинцева А. Л. Влияние отпуска и фрикционного нагрева на износостойкость стали У8, закаленной лазером // Трение и износ. $-1991 .-$ Т. 12 , № 5. - C. 870-878.

Gorkunov E. S. / Magnetic structural-phase analysis as applied to diagnosing and evaluating the lifetime of products and structural components. Part 1 
52. Korshunov L. G., Makarov A. V., Chernenko N. L. Structural aspects of wear resistance of martensitic steels // The Physics of metals and metallography. - 1994. - Vol. 78, no. 4. - P. 442-453.

53. Magnetic and electromagnetic methods of evaluating the wear resistance of steel products / E. S. Gorkunov, V. M. Somova, A. V. Makarov, L. Kh. Kogan, L. G. Korshunov // Russian Journal of Nondestructive Testing. - 1995. - no. 6. - P. 427-432.

54. Морозова В. М., Михеев М. Н., Поморцева Л. В. Магнитные и электрические свойства сталей 17ХН2, 20Х3А, 17Х3МА и цементированных слоев на их основе // Дефектоскопия. -1966 . - № 5. - С. 7-17.

55. Михеев М. Н. Магнитный метод контроля толщины закаленных, цементированных, азотированных и обезуглероженных слоев на стальных изделиях // Изв. АН СССР (ОТН). - 1943. - № 5-6. - C. 53-68.

56. Kuznetsov I. A., Somova V. M., Skripova N. M. Magnetic, electrical and mechanical properties of $12 \mathrm{KhN} 3 \mathrm{~A}$ steel and it's case-hardened layers // The Soviet journal of nondestructive testing. - 1974. - Vol. 10, no. 4. - P. 464-468.

57. Магнитные, электрические, механические свойства сталей 20ХГР, 20ХГНР и их цементированных слоев / И. А. Кузнецов, В. М. Сомова, Т. П. Царькова, Ю. П. Башкиров // В кн.: Структура и свойства твердых тел. - Свердловск : УрГУ, 1973. Вып. 1. - С. 164-184.

58. Kuznetsov I. A., Skripova N. M. Magnetic, electrical and mechanical properties of $12 \mathrm{KhN} 3 \mathrm{~A}$ and $12 \mathrm{Kh} 2 \mathrm{~N} 4 \mathrm{~A}$ steels and of case-hardened layers on them // The Soviet journal of nondestructive testing. - 1982. - Vol. 18, no. 12. - P. 985-990.

59. Kuznetsov I. A., Tsarkova T. P., Shepelev E. V. Electromagnetomechanical properties of cold-worked and heat-treated 11YuA steel // The Soviet journal of nondestructive testing. - 1978. - Vol. 14, no. 1. - P. 17-23.

60. Using coercimeters with attached electromagnets to inspect massive steel objects / M. N. Mikheev, L. A. Fridman, V. M. Morozova, V. P. Tabachnik, G. V. Biba, E. S. Gorkunov, G. S. Chernova // The Soviet journal of nondestructive testing. - 1978. - Vol. 14, no. 8. - P. 713-717.

61. Магнитный контроль глубины закаленного слоя и твердости стальных деталей, закаливаемых токами высокой частоты / М. Н. Михеев, И. А. Кузнецов, Г. С. Томилов, С. Д. Филиппов // Труды ИФМ АН СССР. - Свердловск, 1959. - Вып. 21. - С. 205-208.

62. Магнитный контроль глубины активного закаленного слоя валков холодной прокатки / М. Н. Михеев, В. М. Морозова, Г. С. Томилов и др. // Заводская лаборатория. - 1956. - № 1. - C. 52-56.

63. Effects of coercive force and thickness of tested articles on the outputs of coercive force meters having an attached electromagnet / M. N. Mikheev, V. M. Morozova, G. V. Surin, et al. // The Soviet journal of nondestructive testing. -1970 . - no. 5. - P. $575-577$.

64. Magnetic methods of checking the depth of the hardened layer of machine saw blades / E. S. Gorkunov, V. G. Ermolaev, B. M. Lapidus, N. A. Lyashenko, V. G. Sterkhov, A. I. Ulyanov // The Soviet Journal of Nondestructive Testing. - 1981. - Vol. 17, no. 11. - P. 878-881.

65. Mikheev M. N., Gorkunov E. S., Vostrotina T. I. Inspecting the heat-treatment quality of higt-frequency induction-hardened parts // The Soviet Journal of Nondestructive Testing. - 1976. no. 1. - P. 49-52.

66. Quality control of the case hardening of steel products made from steel 45 / E. S. Aldicheva, M. M. Valiev, Z. G. Kaganov, S. T. Kusimov // The Soviet journal of nondestructive testing. 1976. - Vol. 12, no. 6. - P. 612-614.

67. Горкунов Э. С., Лапидус Б. М. Магнитные свойства двухслойных ферромагнетиков применительно к контролю качества поверхностно упрочненных изделий // Сб. Структурнофазовые превращения в металлах: проблемы прочности и пластичности. - Свердловск : УНЦ AH CCCP. - 1987. - C. 103-110.

68. Горкунов Э. С., Лапидус Б. М. Электромагнитные методы и средства контроля каче- 
ства поверхностного упрочнения стальных изделий. - Свердловск : РИСО УНЦ АН СССР, 1986. -47 c.

69. Горкунов Э. С., Лапидус Б. М. Магнитные методы контроля качества поверхностного упрочнения стальных изделий. - Свердловск : РИСО УНЦ АН СССР, 1986. - 56 с.

70. Lapidus B. M., Gorkunov E. S., Voronov S. F. A magnetic method of determining the structural state and thickness of hardened layers on steel components // Russian Journal of Nondestructive Testing. - 1992. - Vol. 74, № 6. - P. 593-597.

71. Gorkunov E. S., Zakharov V. A. Coercimeters with magnetic attachments (Review) // Russian Journal of Nondestructive Testing. - 1995. - № 8. - P. 625-641. 